\title{
Obřady loučení se zesnulými: Sekulární, náboženské nebo raději žádné pohřby?
}

\author{
Last Rites: Secular, Religious or Rather No Funeral Ceremonies?
}

\author{
Olga Nešporová
}

\begin{abstract}
Contemporary Czech last rites follow noticeably those from the Communist era, during which significant part of religious funerals was replaced by forcibly introduced secular funerals. The paper describes and analyzes contemporary funeral practices with background knowledge of this path dependency. Mixed method approach was applied, and two different data sets were used. Firstly, data from Czech part of the International Social Survey Programme (ISSP) - Religion III. gathered in 2008 was analysed to find out general ideas about proportions of preferred type of funeral ceremonies (religious, civil or none) amongst Czechs, with special attention given to residents in Central Bohemia Region and Prague. Secondly, qualitative field research conducted by the author in three towns in Central Bohemia provides deeper insight into contemporary funeral practices and its meaning according participants. Combining of these two data sources enables the author not only to describe most common secular and religious funeral ceremonies, but also to explain current public attitudes toward the last rites, which are utterly unusual in European and worldwide comparison. The fact that secular funerals are more popular than religious ceremonies belongs to most striking features, as well as recently spreading practice of cremation without any public funeral ceremony.
\end{abstract}

KEY WORDS last rites, civil funeral, religious funeral, Czech Republic

\section{Úvod}

Smrt patr̂́ mezi krizové situace, se kterými se musí vyrovnávat jednotlivci i celá společenství. Podle sociálních konstruktivistů P. L. Bergera a T. Luckmanna (1999) jde o to, jak zařadit smrt do vlastního symbolického světa a legitimizovat ji. To je nejčastěji řešeno právě s pomocí mytologických, náboženských či metafyzických výkladů reality, ale stejného výsledku lze dosáhnout také bez nich. Zejména $\mathrm{v}$ pozdně moderních společnostech mohou tuto funkci plnit i nenáboženské výklady reality, a tak může např́íklad ateista legitimizovat smrt prostřednictvím vlastního světonázoru, třeba s pomocí teorie progresivní evoluce nebo jakkoliv jinak. Legitimizace smrti je úspěšná tehdy, když zajistí dvě základní věci. Zaprvé když umožní jedinci „žít ve společnosti i po smrti významných druhých“ a za druhé když pomůže „zmírnit jeho strach z vlastní očekávané smrti natolik, aby mohl i nadále vykonávat

Sociální studia. Katedra sociologie FSS MU, 2/2011. S. 57-85. ISSN 1214-813X.

1 Studie je výstupem projektu č. 403/08/0720 - „Proměny české religiozity v mezinárodním srovnání, ISSP 2008“ podpořeného Grantovou agenturou České republiky. 
povinnosti každodenního života“ (Berger a Luckmann 1999: 102). Legitimizace smrti prostřednictvím symbolického světa přitom funguje nejen na úrovni individuální, ale i kolektivní, čímž zajištuje trvání společnosti.

Zatímco Berger a Luckmann považovali vyrovnání se se smrtelností za jeden z nejzávažnějších úkoli̊ symbolických světů (Berger a Luckmann 1999: 101) a věnovali se prakticky výhradně rovině kognitivní, jiní autoři se při řešení stejné otázky zaměřili také na úroveň praktického života. Mám na mysli např́klad strukturální funkcionalisty, pro které byla smrt rovněž zásadním tématem. B. Malinowski považoval smrt za jeden $\mathrm{z}$ nejdůležitějǐích zdrojů vzniku náboženství vủbec (Malinowski 1954) a podobně se i T. O'Dea domníval, že vyrovnání se se smrtí je jednou z šesti základních funkcí náboženství (O’Dea a O’Dea Aviad 1983). Malinowski se zabýval rituály založenými na náboženských nebo mytických základech, které $\mathrm{v}$ realitě pomáhaly domorodcům vyrovnat se $\mathrm{s}$ vlastní smrtelností. Poukazoval přitom na skutečnost, že jím zkoumané domorodé společnosti jsou $\mathrm{v}$ mnohých rysech (včetně přístupu ke smrti a mechanismů vyrovnání se s ní) bližší moderním společnostem, než by se na první pohled mohlo zdát (Malinowski 1954: 47). I v současných pozdně moderních společnostech platí, že se smrtí se člověk sice vyrovnává v rovině myšlenkové, ale mohou mu k tomu pomáhat také různé ritualizované úkony.

Ze současných autorů je to např́klad britský teolog a sociální antropolog D. Davies, kdo považuje pohřební rituály za úspěšnou lidskou adaptaci na smrt (Davies 2002: 224). Sociální studia smrti tak nelze ochudit o oblast rituálů, které v rozličných podobách nalézáme ve všech společnostech. Můžeme je přitom rozdělit na ty, které se konají již při umírání, a ty, které následují až po smrti. Ty první se v současné české společnosti konají spíše výjimečně, ${ }^{2}$ zatímco ty druhé, spojené především s pohřbíváním těla, jsou výrazně častější. Doprovází jak uložení těla do země (inhumaci), tak kremaci, nebo to, co jí ze sociálního hlediska bezprostředně předchází.

V současné české společnosti prritom podíl kremací daleko převyšuje podíl inhumací, pohřeb žehem podstoupí zhruba $80 \%$ zesnulých (Společnost prátel žehu 2009: 42), což je jeden z nejvyšších podílů kremací v Evropě. Veliká obliba kremací, které se konají pro více než 70 \% zemřelých, je charakteristická také pro Švýcarsko, Dánsko, Velkou Británii a Švédsko (Davies a Mates 2005: 455-456). ${ }^{3}$ S výjimkou České republiky se jedná o země s převážně protestantskou náboženskou tradicí, což je vysvětlováno jednak tím, že reformace ideově oddělila pohřební ritus od př́mých důsledků pro další osud zesnulého (Jupp 2006), jednak tím, že jde o důsledek sekularizace (Jupp 2006, Davies a Mates 2005). V př́ípadě české společnosti nepochybně platí druhé vysvětlení. Protestantské církve kremaci vesměs velmi záhy přijaly jako možnou formu pohřbívání, zatímco církev římskokatolická ji dlouho vnímala jako demonstraci proticírkevních postojů, kterou ve svých počátcích (od 70 . let 19. století, kdy se realizovaly první evropské moderní kremace, až zhruba do 2 . světové

2 Římskokatolická svátost někdy (zejména dříve) nazývaná „poslední pomazání“ je dnes používána spíše jako obecná podpora nemocných, čemuž odpovídá také úprava názvu na „,pomazání nemocných“ (viz Adam 2001).

3 Nejnovější statistiky o podílech kremací v různých státech světa lze nalézt na internetových stránkách The Cremation Society of Great Britain: <http://www.srgw.demon.co.uk>. 
války) mnohdy skutečně byla (Davies a Mates 2005). Ř́mskokatolická církev príijala kremaci jako alternativu k tradičnímu pohřbu do země na Druhém vatikánském koncilu v šedesátých letech 20. století, zatímco pravoslavná církev kremaci dodnes pro své věřící jako adekvátní způsob pohřbení neschvaluje.

Rozšiření kremace jako nového způsobu pohřbívání přitom mělo závažný dopad na konání pohřebních obřadů, nebot' umožnilo rozšíriti jejich variabilitu, včetně nově zaváděných necírkevních či sekulárních forem pohřebních ritů. $\mathrm{V}$ českém prostředí lze jasně oddělit tři období vývoje těchto sekulárních obřadů.

V prvním období - od konce 19. století ${ }^{4}$ zhruba do roku 1948 - byla hojně využívána ideologie prokremačního hnutí spjatého (i personálně) s antiklerikálním hnutím Volná myšlenka. Provázel-li kremaci sekulární obřad, ${ }^{5}$ měl zhruba následující rysy. V ideálním případě se konal v obřadní síni krematoria, mnohdy označované jako „kaple“, kde byla na katafalku vystavena rakev a pozůstalí se symbolicky loučili se zesnulým (Mencl 1922, Nozar 1931). Pohřební obřad byl záměrně nazýván „úmrtní slavností“ (Kunstovný, nedatováno: 14), aby byla zdůrazněna jeho odlišnost od běžných, tedy náboženských - smutných a ponurých pohřebních obřadů. Pohřební proslov jednak zahrnoval obecné „moderní“ úvahy týkající se života a smrti, jednak připomínal a oslavoval život zesnulého. Pronášel jej nejčastěji př́ítel zesnulého nebo zástupce spolku Krematorium. V proslovech byl kladen důraz na život, nikoli na smrt, která ovšem nebyla prezentována jako definitivní konec života. Podobně jako při náboženských obřadech byla smrt „překonávána“ poukazem na posmrtnou existenci. Byla totiž připomínána nekonečnost vesmíru, „kde se vše proměňuje, ale nic neumírá“ (Nozar 1931: 15), jedna forma života $v$ této koncepci stř́́dala jinou a život jako takový byl považován za věčń (Pohřební proslovy 1930). K útěše pozůstalých měla sloužit také další složka proslovu, připomenutí samotné osobnosti a života zemřelého, který symbolicky přežívá ve svých činech a práci, kterou pro ostatní vykonal, reálně pak prostřednictvím svých potomků (tamtéž).

Druhé období, spojené s komunistickým režimem (1948-1989), bylo specifické zcela programovým a shora řízeným mohutným rozšsiřením kremací a sekulárních pohřebních obřadů. Cílem přitom bylo oslabení vlivu náboženství a církví ve společnosti (Loukotka 1979: 252-257, Nešporová 2007, Sošková 1984). Nárůst sekulárních pohřbů byl patrný již v 50. letech, v roce 1955 tvořily v tehdejší ČSR téměř čtvrtinu všech pohřbů a v dalších desetiletích se ještě více rozšriřily, takže $\mathrm{v}$ roce 1987 již byla většina pohřbů - zhruba tř̌i pětiny - sekulárních. ${ }^{6}$ Průběh obřadů přitom jednak navazoval na předchozí necírkevní pohřební obřady konané $\mathrm{v}$ krematoriích, jednak kopíroval ruský model občanského pohřbu

4 Prokremační hnutí v českých zemích aktivně působilo od konce 19. století (v roce 1899 byla založena Společnost pro spalování mrtvol, v roce 1909 pak spolek Krematorium), kremace však byly oficiálně povoleny až po vzniku Československého státu v roce 1919, předtím musely probíhat v zahraničí (viz Lenderová 2001, Nešpor a Nešporová 2011).

5 Spojení kremace se sekulárními obřady nebylo automatické, např́klad Církev československá (husitská) a Českobratrská církev evangelická již od 20. let 20. století kremace schvalovaly, podporovaly budování kolumbárií a konaly církevní obřady doprovázející kremace (Kordule 1937).

6 Přibližné podíly sekulárních pohřebních obřadů jsem odvodila dopočtem $\mathrm{z}$ dat uváděných V. Babičkou o počtech ř́mskokatolických pohřbů (Babička 2005: 479-480). 
(viz Merridale 2000). Ustoupil prvorepublikový důraz na estetiku, obřady měly být především funkční. Postupně byly budovány sekulární obřadní síně, mnohde vzniklé rekonstrukcí církevních staveb. Obsah obřadů byl upraven tak, aby konvenovaly politickým záměrům vládnoucího režimu. Ideální občanský pohřební obřad měl prostřednictvím proslovů plnit nejen funkci sociální, ale i výchovnou. Proto musel vedle údajů o životě mrtvého (vyzdvihujících především jeho pracovní výsledky) obsahovat rovněž obecnější světonázorové myšlenky, jejichž základem bylo materialistické a marxistické hledisko. Časté bylo zařazení přednesu poezie nebo alespoň nějakého citátu konvenujícího komunistickým idejím (Škvarka 1975). Žádné úvahy o posmrtné existenci se naproti tomu nepřipouštěly, smrt byla vnímána jako absolutní konec, $\mathrm{k}$ jehož překonání vedla toliko práce a činy, které mrtvý vykonal pro budoucí generace při budování socialistické společnosti. Řečníci byli zástupci pracovních kolektivů a „budovatelé socialismu“ organizovaní prostřednictvím místních sborů pro občanské záležitosti. Živá hudba byla zvolna nahrazována reprodukovanou (Navrátilová 1989, Sošková 1984, Občanské obřady 1978).

Třetí období nastalo po roce 1989 a trvá dodnes. I ono jasně navazuje na předchozí praxi a právě jemu je věnována následující studie. Současná česká společnost je totiž v evropském a vlastně i celosvětovém kontextu specifická (mimo jiné) právě pohřebními obřady. A to hned ve dvou ohledech. Za prvé jsou Češi ${ }^{7}$ velmi často pohřbíváni s občanskými pohřebními obřady a nikoliv náboženskými, jak je stále běžné ve většině společností. Za druhé je $\mathrm{v}$ české společnosti nebývale rozšiřený zvyk pohřbít tělo bez toho, aby se konal jakýkoliv kolektivní pohřební obřad. Přesné statistiky o počtech a typech konaných pohřebních obřadů bohužel neexistují, přesto lze jejich podíly z různých zdrojů velmi zhruba odvodit. Napríílad v této studii jsou pro hrubý přehled zastoupení sekulárních, náboženských či žádných pohřebních obřadů ve středních Čechách a ČR využita jednak data poskytnutá dvěma zkoumanými pohřebními organizacemi, jednak data z výzkumu ISSP, kde respondenti vyjadřovali své preference ohledně typu vlastního pohřebního obřadu. Mezinárodní srovnání lze provádět pouze na základě srovnání zahraničních studií věnovaných současné pohřební praxi, které ovšem využívají téměř vždy kvalitativní metodologii a zastoupení jednotlivých typů obřadů nekvantifikují. Srovnatelné kvantitativní údaje existují pouze pro zastoupení kremací a pohřbů do země (viz Davies a Mates 2005 či internetové stránky The Cremation Society of Great Britain - viz http://www.srgw.demon.co.uk).

I přes nedostatek konkrétních dat je při sledování pohřebních obřadů v mezinárodním kontextu zřejmé, že míra rozšǐření sekulárních pohřebních obřadů je v České republice jedna $\mathrm{z}$ nejvyšších na světě. $S$ podobně vysokými podíly se lze setkat pouze v Německu, přesněji řečeno $\mathrm{v}$ jeho bývalé východní části, kde je současný stav jasným pozůstatkem praxe nastolené v období socialistické NDR. ${ }^{8}$ Obě socialistické společnosti (československá i východoněmecká) si byly velmi blízké, jak co se týká procesů radikálního eliminování vlivu církví

7 Termín „Češi“ používám obecně pro označení obyvatele České republiky bez ohledu na konkrétní etnickou, národnostní nebo jinou př́íslušnost.

8 Zatímco $\mathrm{v}$ bývalém východním Německu jsou občanské pohřby běžné, $\mathrm{v}$ bývalém západním Německu je sekulární jen zhruba každý desátý pohřeb. Termín „sekulární“ přitom znamená především „necírkevni““ a označuje neúčast duchovního. Pohřební obřad vede profesionál (Redner), 
ve společnosti, tak masovým rozšířením kremací a sekulárních pohřebních obřadů (srovnej Schulz 2005). V žádné jiné zemi někdejšího Východního bloku se nepodařilo dosáhnout tak vysokého podílu občanských pohřbů a eliminace náboženské složky pohřebních obřadů. Ve druhé polovině 20. století byly pozorovány značné změny v př́stupu ke smrti a v konání pohřebních obřadů rovněž v západoevropských společnostech (Ariès 1976, Elias 1998, Gorer 1967, Howarth 2007, Walter 1994), týkaly se ovšem především obecnějších postojů ke smrti (jejího zakrývání, „tabuizace“), zatímco v případě pohřebních obřadů pak šlo především o jejich zjednodušení a privatizaci, zejména v oblasti truchlení. Necírkevní či sekulární pohřební rity nabízelo dle odborníkủ studujících pohřební obřady ještě na začátku 21. století jenom relativně málo osob (Davies a Mates 2005: xxii, 373). V mnohých státech se ovšem zvolna začínají při provádění pohřebních obřadů uplatňovat sekulární osoby, tzv. celebrants, které vedou pohřební obřady namísto duchovních (případně i obřady další, například svatby, oslavy narození dítěte atd.). Jejich služby využívají zejména lidé, kteří nechodí do kostela, a proto jim církevní pohřeb připadá nepríípadný. Nemusí to ovšem nutně znamenat, že by obřady vedené těmito profesionály postrádaly náboženskou složku. Ze západních zemí jsou nejhojněji rozšriřené např́ílad v Nizozemsku nebo na Novém Zélandu (Schäfer 2005; Venbrux, Perlen a Altena 2009). Zájem o služby „celebrantư “ poslední dobou vzrůstá, i když se stále jedná o minoritní záležitost. Např́iklad ve Velké Británii, kde bohoslužby pravidelně navštěvuje pouhý zlomek populace, tvoří necírkevní pohřby nejvýše několik procent všech pohřbů. ${ }^{9}$

Zjistit údaje o absenci jakéhokoliv kolektivního pohřebního obřadu v různých zemích světa je ještě obtížnější. Ve většině společností je konání nějakého pohřebního obřadu považováno za naprostou samozřejmost, proto autory většinou ani nenapadne tematizovat jejich možnou absenci. I v př́ípadech konání tzv. sociálních pohřbů, kdy je zesnulý pohřben na náklady obce, se běžně nějaký veřejný kolektivní pohřební obřad koná (může být realizován pro více zesnulých najednou). ${ }^{10}$ Pouze belgická socioložka F. Vandendorpe zmiňuje, že kremace může $v$ Belgii proběhnout $i$ bez obřadu, zároveň však uvádí, že ve většině př́padů rodina a blízcí príbuzní rakev do krematoria doprovází a účastní se zde obřadu (Vandendorpe 2000: 25). Další možností je uspořádání nějakého vzpomínkového obřadu či vzpomínkové slavnosti bez př́tomnosti těla zesnulého. Takový obřad se pak nemusí konat v obřadní síni krematoria ani v jiné smuteční síni, ale může probíhat prakticky kdekoliv, např́klad v kostele

který do něj často na požádání rodiny nějakou náboženskou složku začleňuje, např́íklad modlitbu, čtení žalmů, zmínku o vzkř́íšení atd. (Downey 1998).

9 Pro Velkou Británii odhaduji maximálně tř̌i procenta necírkevních pohřbů z celkového počtu pohřbů. Organizovány jsou nejčastěji za pomoci British Humanist Association (ta v roce 2000 uspořádala o něco více než 4000 pohřbů z celkového počtu více než 600000 , tj. cca $0,66 \%$; Davies 2002: 215, 227) nebo s pomocí centrálně organizovaných Civil Celebrants (viz http://www.iocf. org.co.uk).

10 Podle tajemníka německého svazu pohřebnictví R. Lichtnera jde o běžnou praxi např́iklad v Německu (přednáška dne 10. 5. 2007 na veletrhu pohřebnictví VENIA v Brně), francouzská socioložka D. Hervieu-Léger zase popisuje konání kolektivního pohřebního obřadu (sekulárního, ovšem s užitím četné křest'anské symboliky) pro zesnulé pařǐžské bezdomovce (Hervieu-Léger 2004). 
či jiném sakrálním prostoru, $v$ bytě či na zahradě pozůstalých, $v$ restauraci atd. Může být uspořádán například pro zesnulé, kteří věnovali své tělo pro medicínské účely (viz Walter 1990: 2-3, 35). Kremace pak nabízí ještě jednu možnost, a tou je uspořádání obřadu posledního rozloučení při konečném uložení popela. Takový obřad pak zpravidla bývá doplněním předchozích obřadů a završením období truchlení, ${ }^{11}$ ale někdy patrně může být $\mathrm{i}$ jediným konaným obřadem. Na základě existující literatury se ovšem nezdá, že by v evropském prostoru byla taková náhrada $\mathrm{v}$ současnosti nějak masově uplatňována.

Naprostou absenci pohřebního obřadu okrajově zmiňují pouze dva současní britští sociologové. T. Walter, který hojně kritizuje dnešní podobu anglických (většinově církevních) pohřbů pro jejich neosobnost, přetvářku a byrokratičnost, se $\mathrm{v}$ jedné ze svých prací $\mathrm{s}$ trochou nadsázky zmiňuje o tom, že se nelze divit myšlenkám mnohých Angličanů na to, že by se bez pohřbu zcela obešli (Walter 1990: 9). Samotná tato poznámka však svědčí o tom, že v současné Británii prakticky není možné pohřební obřad nekonat. ${ }^{12} \mathrm{G}$. Howarth interpretovala situace, kdy se v souvislosti s lidským úmrtím a pohřbením nekoná žádná ceremonie, jako jev, kdy je $\mathrm{v}$ dané kultuře degradován lidský život, stav, který souvisí se znehodnocením etnických, náboženských a nacionálních identit dané společnosti (Howarth 2007: 246). Sama však neuvádí př́iklad žádné společnosti, ve které by pohřební obřady absentovaly. Aktuální české specifikum dané značným množstvím nekonaných pohřebních obřadů může mít svoji obdobu opět snad jen v některých oblastech bývalého východního Německa (odhadovaný podíl pohřbů bez obřadu byl podle tajemníka německého svazu pohřebnictví pro celou SRN v roce 2005 zhruba $5 \%){ }^{13}$

Cílem této studie je upozornit na dvě uvedená česká specifika v oblasti pohřbívání a pokusit se je vysvětlit. Výzkum prritom vychází především ze stavu zjištěného ve středních Čechách a Praze, tedy v lokalitách, kde je sekulární a bezobřadné pohřbívání spiše častější, jak naznačují níže uvedená celorepubliková data sledující preference obyvatelstva pro konání pohřebních obřadů. Ve snaze pochopit současný stav obřadů spojených s pohřbíváním je přitom kladen důraz na aktérská hlediska a významy, které současníci pohřebním obřadům připisují. V návaznosti na tyto informace se pak snažím vysvětlit prríčiny rozširření bezobřadného pohřbívání.

\section{Metodologie a data}

Pro úplnější popis a interpretaci zkoumané problematiky použivám kombinované metody (Creswell a Plano Clark 2007) a propojuji data ze dvou samostatných výzkumů kvantitativního celorepublikového šetření ISSP 2008 a kvalitativního výzkumu zaměřeného

11 Francouzský antropolog R. Hertz zaznamenal, že konečné uložení ostatků probíhající při tzv. sekundárním pohřbu má v mnoha kulturách ústřední symbolický význam jak pro další osud zesnulého (stával se „předkem“), tak pozůstalých (ukončení období truchlení) (Hertz 1960).

12 Pokud nejsou Britové spokojeni s nabídkou pohřebních služeb a církevních obřadů, mají možnost aktivně se podílet na pohřbívání svých blízkých prostřednictvím tzv. do it yourselffunerals, které se sice rozšiřují, ale rozhodně jsou stále marginální záležitostí (Walter 1990, Wienrich a Speyer 2003).

13 Přesné statistiky neexistují. Německé sdružení pohřebnictví usiluje o to, aby byly př́ípady bezobřadného pohřbívání v Německu zcela vymýceny (přednáška R. Lichtnera dne 10. 5. 2007 na veletrhu pohřebnictví VENIA v Brně). 
na představy o posmrtné existenci a pohřební obřady, který jsem realizovala v letech 2003 2008 na území Středočeského kraje a v Praze.

První výzkum je součástí mezinárodního výzkumného projektu International Social Survey Programme (ISSP), v jehož rámci je prưřezové, tematicky vyhraněné šetření (témata se zhruba po deseti letech opakují) každoročně prováděno ve zhruba 45 státech celého světa. Využívám přitom česká data $\mathrm{z}$ roku 2008, kdy bylo šetření zaměřeno na náboženství a já jsem měla jako členka týmu možnost přidat do rozhovoru otázku týkající se pohřebních obřadů. ${ }^{14} \mathrm{~K}$ dispozici tak máme poměrně unikátní soubor dat, která obsahují jak podrobné informace o respondentově náboženském vyznání, přesvědčení a praxi, tak jeho preference pro typ vlastního pohřebního obřadu - náboženský, sekulární nebo žádný. Data byla pro Sociologický ústav Akademie věd ČR, v.v.i., sebrána formou standardizovaných rozhovorů agenturou Factum Invenio. Respondenti byli vybráni pravděpodobnostním stratifikovaným výběrem a návratnost činila $46 \%$.

Výzkumný vzorek čitá 1512 respondentů a měl by představovat reprezentativní výběr populace ČR starší 18 let. S ohledem na lokalitu provedeného kvalitativního výzkumu v této studii pracuji převážně $s$ daty ze Středočeského kraje a hlavního města Prahy, celorepubliková data jsem použila pro obecnější přehled a vymezení krajových specifik v preferovaných typech pohřebních obřadů. Pracovala jsem s daty váženými podle posledního Sč́tání lidu, domů a bytů z roku 2001 (váhy zohledňují kraj, velikost místa bydliště, pohlaví, věk, vzdělání a počet členů domácnosti). Za významné jsem považovala i odpovědi ,je mi to jedno“, a „neumím vybrat“, proto je z analýz nevypouštím.

Druhý, - a pro tuto studii klíčový - kvalitativní výzkum jsem realizovala ve třech městech Středočeského kraje a ve čtyřech pražských náboženských skupinách. ${ }^{15}$ Prostřednictvím tohoto šetření lze hlouběji nahlédnout do myšlení a představ současníků (nejčastěji ve střední věkové kategorii 30-50 let věku) týkajících se smrti, víry v posmrtný život a pohřebních obřadů. Výzkum byl poměrně obsáhlý, v průběhu pěti let jsem realizovala nestandardizované rozhovory na téma smrti a pohřebních rituálů celkem se zhruba 80 osobami (běžnými lidmi i odborníky), a navíc jsem prováděla zúčastněná pozorování náboženské a pohřební praxe. V rámci výzkumu jsem vedla rozhovory s pracovníky trrí středně velkých pohřebních ústavư ${ }^{16}$ a jednoho městského hřbitova.

Výzkumný vzorek jsem vybrala účelově, oslovovala jsem osoby středního věku (30-50 let) ochotné poskytnout rozhovor o smrti a pohřebních obřadech. Z hlediska náboženství jsem zvolila osoby na opačných pólech. První byli věrící, ovšem pouze praktikujícíi ${ }^{17}$ členové

14 Otázka zněla: „Kdybyste zemřel/a, jaký typ pohřbu byste si přál/a?“V V̌etřeních jiných státu otázka zaměřená na pohřební obřady nebyla.

15 Podrobnější popis výzkumu i jeho komplexnějších výstupů lze najít v mojí disertační práci (Nešporová 2008).

16 Při podrobnějších popisech pohřební praxe a zastoupení jednotlivých typů obřadů vycházím z opakovaných rozhovorů s pracovníky dvou pohřebních ústavů, které dohromady každoročně zajišt'ovaly pohřbení asi 500 mrtvých těl. Majitel třetího pohřebního ústavu se mnou sice i přes původní odmítnutí krátce pohovořil, ovšem odmítl dát souhlas k nahrávání rozhovoru. Přesto poskytnuté informace považuji za důležité a při interpretacích s nimi pracuji.

$17 \mathrm{Tj}$. navštěvující společné bohoslužby. 
konkrétních náboženských skupin. Druhou byli „nevěříci““, které jsem pro účel výzkumu definovala jako osoby nehlásící se přímo $\mathrm{k}$ žádnému konkrétnímu náboženskému vyznání, církvi či náboženské skupině. Nepraktikující věřící nebyli do výzkumného vzorku zařazeni. V letech 2003-2004 byly vedeny rozhovory se členy čtyř vybraných pražských náboženských skupin - Církve římskokatolické, Českobratrské církve evangelické, Náboženské společnosti Svědků Jehovových a Hnutí Hare Krišna. Volba církví či náboženských společností zohledňovala jejich zastoupení a význam v české společnosti. Za prvé byly zvoleny skupiny, jejichž členská základna je v České republice rozsáhlá, a za druhé skupiny, jejichž přesvědčení výrazně kontrastuje s prvně zmíněnými, aby bylo možné poukázat na potenciální variabilitu perspektiv věřících. V roce 2006 byly realizovány rozhovory s nevěřícími. Stejně jako $\mathrm{v}$ případě aktivních věřících jsem se přitom snažila dodržet přibližně stejné zastoupení žen a mužů (celkem 29 žen a 29 mužů). ${ }^{18}$

Charakteristické bylo, že ženy byly častěji ochotné zúčastnit se výzkumu a poskytnout rozhovor. Věřící byli oslovováni většinou po bohoslužbách, přičemž svolení $\mathrm{k}$ rozhovoru na téma smrti u nich bylo četnější než u nevěřících. Zatímco věřící ( 28 osob) byli z Prahy, nevěříí (30 osob) žili v jednom středočeském městě se zhruba čtyřmi tisíci obyvateli. Po počátečních neúspěších, kdy se mi nepodařilo kontaktovat nevěřící informátory prostým oslovením v jejich domovech, ${ }^{19}$ jsem využila sít' styčných osob, které znaly obyvatele dané lokality, mohly tak oslovit potenciální informátory př́slušného věku a získat jejich předběžný souhlas s provedením rozhovoru a telefonický kontakt, takže jsem pak už jen domluvila místo a čas rozhovoru. Omezeně byla dále využita i metoda sněhové koule. Časový rozsah rozhovoru byl velmi kolísavý, závisel především na výřečnosti informátora, i na tom, kolik měl se smrtí a pohřbíváním zkušeností, nakolik měl tuto oblast promyšlenou a do jaké míry se chtěl o své představy se mnou dělit. Průměrná délka zvukového záznamu rozhovoru činila tři čtvrtě hodiny, přičemž věřící měli většinou $\mathrm{k}$ tématu smrti více co říci než nevěrící. Výběr pohřebních ústavů byl dán lokalitou, do výběru byly zahrnuty tř̌i největší, které pro obyvatele zkoumaného středočeského města zajišt'ují pohřební služby. Rozhovory s pracovníky pohřebních služeb (i zaměstnanci hřbitova) pak byly zaměřeny na zkušenosti z jejich praxe při kontaktech s klienty, na poptávku i nabídku služeb a na průběh nejčastěji realizovaných pohřebních obřadů.

Všechny rozhovory byly nahrávány a následně byly pořízeny jejich doslovné přepisy, se kterými jsem pracovala při analýzách. Kódování jsem prováděla za pomoci software ATLAS.ti.

\section{Nejčastěji konané pohřební obřady}

Z provedených výzkumů je jasně patrná kontinuita mezi předlistopadovou a současnou pohřební praxí. Dřívější státní či městské pohřební služby se po roce 1989 rychle přeměnily

18 V rámci jednotlivých skupin ovšem není rozdělení přísně poloviční, mezi praktikujícími věŕícími mírně převažovali muži, zatímco mezi nevěřícími ženy.

19 Strategie se ukázala jako nevhodná, lidé nebyli ochotni poskytnout rozhovor o smrti, at' již z opravdové nechuti zabývat se tímto tématem nebo i z toho důvodu, že mě považovali za misionáŕku nějaké náboženské skupiny či církve, nejčastěji asi svědkyni Jehovovu. 
v soukromé firmy, př́padně se staly př́ispěvkovými organizacemi, personál však zůstal tentýž a kontinuita byla tedy prakticky neporušena. I to je důvodem, proč $\mathrm{k}$ žádným převratným změnám v pohřbívání a konání pohřebních obřadů s př́íchodem nového politického režimu nedošlo. Ovšem s jedinou výjimkou, a tou je mohutné rozšǐření praxe pohřbít, respektive spálit mrtvého bez pohřebního obřadu.

Při popisu současných pohřebních obřadů vycházím z běžné praxe tř́i měst Středočeského kraje. Jedná se o oblast $\mathrm{v}$ rámci republiky charakteristickou spiše menšími a jednoduššími pohřby, s větším sekulárním než náboženským vlivem a s hojným zastoupením pohřbů bez obřadu či toliko privátních, neveřejných rozloučení konaných pouze pro úzký okruh nejbližších (př́buzných) zesnulého.

Ve zkoumané lokalitě probíhají pohřební obřady nejčastěji následujícím způsobem. Obřad „posledního rozloučení“ se zesnulým se koná v sekulární obřadní síni v areálu hřbitova. Na pódiu $\mathrm{v}$ přední části je umístěna uzavřená rakev s tělem mrtvého obklopená smutečními věnci a menšími květinovými dary, které tam příchozí pokládají. Pozůstalí (běžně cca 20-30 osob, generalizace je velmi obtižná) zaujmou místa k sezení v síni tak, že nejbliže rakvi sedí nejbližší príibuzní a prátelé a s přibývající vzdáleností zpravidla narůstá i sociální či príbuzenská vzdálenost vztahu k zesnulému. Jsou-li všechna místa obsazena, zbytek osob, většinou sousedů, známých, pracovních kolegů atd. stojí. Vlastní obřad trvá cca 20 minut a sestává především z poslechu reprodukované hudby, kterou volí objednavatel pohřbu převážně z nabídky pohřební služby. Jedná se nejčastěji o čtyři až pět skladeb vážné hudby, starších populárních písní či české country (mnohdy jde o směs všech těchto možností). Před odehráním posledního hudebního kusu řečník pronese krátkou řeč, trvající zhruba dvě až pět minut (srovnej Maiello 2005).

Délka proslovu závisí na zvyku řečníka a přání rodiny. Může se jednat pouze o poděkování příchozím, nebo proslov zahrnuje ještě nějakou obecnější poetickou připomínku o životě a smrti, často obsahuje verš na toto téma. Většinou je připomenuta osoba zesnulého, alespoň v hrubých rysech je načrtnut jeho život (datum a místo narození, počet dětí, zaměstnání), někdy jsou doplněny také podrobnější údaje týkající se jeho zálib a zásluh, eventuálně dalších pracovních a rodinných záležitostí. Nakonec řečník zpravidla jménem rodiny poděkuje př́ichozím a vyjádří smutek nad odchodem zesnulého. Pro delší proslov je nezbytná spolupráce pozůstalých, aby řečníkovi, který mrtvého nezná, poskytli určité osobní údaje, jejichž připomenutí považují během obřadu za vhodné. Pokud má řečník $\mathrm{k}$ dispozici pouze informace z „parte“, celá pohřební řeč trvá zhruba dvě až tři minuty. Zkušenost pracovnice pohřební služby je spiše taková, že pozůstalí upřednostňují kratší proslov a osobnější informace poskytovat nechtěji:

...ted' to směřuje $\mathrm{k}$ tomu, že ti lidé [pozůstalí] ty podklady dávat nechtějí, že se jim to [pohřební řeč] zdá dlouhé, že on [řrečník] to moc rozvětvuje, a že se od toho ustupuje, bych řekla. Že spíš chtějí, aby to bylo výstižné, stručné, ale přitom chtěli by spíš do toho dát nějakou myšlenku jako životní nebo něco o té smrti spojené s životem. Myšlenku nebo verše. ${ }^{20}$

20 Rozhovor s pracovnicí pohřební služby ve středočeském městě ze dne 30. 11. 2006. Všechny uvedené citace byly z hovorového jazyka převedeny do spisovné formy psané češtiny. Tyto změny jsou drobné (jednalo se většinou o změny koncovek) a rozhodně nemění smysl a obsah výpovědí. 
Uvedená zkušenost ukazuje, že pozůstalí upřednostňují jednodušší formy pohřebních obřadů a zejména jejich mluvené složky. Do určité míry tím negují předchozí praxi z období komunistického režimu, kde byly delš́ řečové proslovy o životních a zejména pracovních úspěších a př́nosech zesnulého pro (socialistickou) společnost běžnějš́i (viz Občanské obřady 1978, Škvarka 1975). Rovněž tím projevují obavy z „nepatřičnosti“ a chtějí se vyhnout schématičnosti proslovu pronášeného profesionálním řečníkem, který dotyčného vůbec neznal. Sekulární kontext totiž nabízí jen málo možností k symbolickému překonání smrti poukazem $\mathrm{k}$ určité transcendentní sfére nebo pokračování života po smrti a př̌i nedostatku dalších osobnějších informacích o zesnulém hrozí, že proslov bude sestávat z množství obsahově vyprázdněných klišé. Poptávka po smysluplném zasazení smrti do kontextu určitého symbolického univerza a vyslovení myšlenek týkajících se vztahu života a smrti je sice patrná, ale při současné nedostatečné spolupráci pozůstalých s řečníkem nemůže být v praxi sekulárních pohřbů adekvátně uspokojována. Chybí totiž jednotný ideový koncept přesahující smrt, který např́iklad náboženské doktríny většinou zajištují poukazem na posmrtnou existenci (a komunistická ideologie jej realizovala prostřednictvím „světské transcendence“).

Po proslovu zazní poslední píseň, př́tomní povstávají a zatahuje se opona nebo rakev zajíždí do zákulisí, čímž se zesnulý symbolicky i fyzicky vzdaluje pozůstalým. Př́tomní pak kondolují, tj. vyjadřují nejbližším př́buzným zesnulého slovy a podáním ruky soustrast nad jejich ztrátou. Společenství se následně rozchází, přičemž užší skupina pozůstalých často pokračuje do restauračního zařízení nebo domova na smuteční hostinu, která je určitým završením pohřbu. Tou se zde však pro její privátní charakter i skutečnost, že jen zř́́dka bývá organizována pohřební službou, zabývat nebudu. Tělo je následně většinou převezeno do krematoria, kde je spáleno a pak v podobě urny s popelem předáno pozůstalým. Může být ovšem rovněž uloženo do země.

Popsaný kolektivní obřad může mít různé obměny. Jednou z nejvýraznějších je vystoupení duchovního namísto sekulárního řečníka. Tím celý obřad nabývá náboženského rozměru a pohřební řeč je pak často výrazně delší. Vedle připomenutí osobnosti zesnulého obsahuje především poukaz na Boha a víru v něj a na vykoupení a zmrtvýchvstání (v př́ípadě křest’anských duchovních, s jinými ve zkoumaných pohřebních službách zkušenost neměli). V př́padě církevního pohřebního obřadu konaného v obřadní síni může být odlišná volba hudby, celkový průběh obřadu se však velmi podobá pohřbům sekulárním a duchovní je omezen volbou prostoru a v něm zažitými zvyky. Další obměnou je vypuštění proslovu, kdy obřad spočívá toliko v poslechu hudby a následném kondolování nejbližším pozůstalým. Jinou možností je naopak vypuštění poslední kondolenční části, o které řečník jménem rodiny požádá přítomné, kteří se pak po doznění hudby tiše rozejdou. Stále hojněji se rozšiřující možností je vyloučení veřejnosti z účasti na pohřebním obřadu. ${ }^{21}$ Rozloučení se pak koná pouze pro malý počet pozvaných príbuzných a nejbližších rodinných přátel. $\mathrm{V}$ těchto prípadech je častější absence proslovu. Někdy může být takovéto soukromé rozloučení pořádáno pouze v čekárně pro blízké pozůstalé (v budově kde je pohřební síň), kde se několik nejbližších zesnulého sejde a má možnost naposledy pobýt $\mathrm{v}$ jeho prrítomnosti, př́ípadně se na něj podívat. Atmosféra je obvykle podbarvena tichou reprodukovanou hudbou.

21 Př́istup veřejnosti je vyloučen tím, že se nepozvaní nedozví, kdy se obřad koná. 
Církevní pohřební obřad může být modifikací uvedeného běžného obřadu za přítomnosti duchovního. Ve zkoumaných lokalitách jsou to často duchovní Československé církve husitské, ale někdy i katoličtí kněží, kteří pohřební řeč v obřadní síni pronášejí. Církevní pohřební obřad „se vším všudy“ se však odehrává v kostele. Pak ještě př́ípadně následuje hromadný přesun (auty nebo pěším průvodem) na hřbitov, kde je tělo za přítomnosti pozi̊stalých, proslovu faráře a s živou hudbou obřadně uloženo do hrobu nebo hrobky. Takové pohřby se však v daných lokalitách konaly výjimečně. Prostor kostela, modlitebny či hřbitova poskytuje duchovním větší možnosti řizení celého obřadu a neomezuje je tolik časově. Celý pohřební obřad se pak více podobá bohoslužbě, kterou vlastně i je. Zkušenost zkoumaných pohřebních služeb ukazuje, že tam, kde je duchovní ochoten účastnit se pohřebního obřadu v běžně užívané obřadní síni, se konají náboženské obřady častěji než v př́padě, že to duchovní odmítá a vyžaduje, aby byl pohřeb vypraven z kostela. Naproti tomu se však stává, že katolický duchovní odmítne účast na pohřebním obřadu osoby, která pravidelně nenavštěvovala bohoslužby a osobně ji nezná. Dochází $\mathrm{k}$ tomu zejména $\mathrm{v}$ př́padech, kdy přítomnost faráře zajištuje pouze pracovnice pohřební služby, pozůstalí chtějí pohřební obřad uspořádat v obřadní síni, případně je obřad plánován na den, kdy má kněz jiný program.

Poslední hojně se rozšiřující možností je zcela ustoupit od pořádání jakéhokoliv pohřebního obřadu. Pozůstalí tak prostřednictvím pohřební služby zajišt’ují pouze kremaci (při ukládání těla do hrobu se varianta „bez obřadu“ prakticky nevyskytuje) bez toho, aby ji doprovázelo kolektivní rozloučení se zesnulým. Tato možnost je v posledních letech stále více využívána, a to nejen $\mathrm{v}$ prípadech, že se nenajde nikdo blízký, kdo by pohřbení mrtvého zajistil, a musí to zařídit obec, na jejímž území daný člověk zemřel. Ve dvou zkoumaných pohřebních službách, které dohromady zajištovaly pohřbení zhruba 500 mrtvých ročně, byla více než třetina těl pohřbena bez obřadu (dle odhadu jednatelky firmy Vavř́n ${ }^{22}$ to byla zhruba jedna třetina, firma Hades pak dle přesných záznamů z platebních knih v roce 2005 realizovala dokonce $42 \%$ prŕípadů pohřbení těla bez obřadu). Skutečnost, že si pozůstalí neobjednají $\mathrm{v}$ pohřební službě konání pohřebního obřadu, nemusí vždy nezbytně znamenat, že si sami nějaké kolektivní shromáždění sloužící $\mathrm{k}$ symbolickému rozloučení se zesnulým (ač bez prítomnosti jeho těla) nezorganizují. Proto je těžké určit, jak jsou př́pady naprosté absence kolektivního pohřebního obřadu či rozloučení časté. Pohřební obřad je navíc možné spojit i s konečným uložením popela, které může být realizováno prakticky kdykoliv a kdekoliv. ${ }^{23}$ Uložení popela a s ním spojené př́ípadné obřady však většinou nezajištují pohřební služby, nýbrž správa hřbitovů. ${ }^{24}$ Obřadné uložení popela na konečné místo na hřbitově za přítomnosti většího počtu pozůstalých se nicméně ve zkoumaných lokalitách dle pracovníků hřbitovů konalo zcela výjimečně a ani rozhovory s ostatními informátory nenasvědčovaly, že by bylo př́liš rozšířené. Ač si pozůstalí mohou zorganizovat vlastní „obřad“ a společně se sejít, zavzpomínat na zesnulého a symbolicky se tak s ním společně rozloučit (at' již bez

Uvedené názvy firem i všechna jména informátorů jsou z důvodu zachování anonymity smyšlená. Česká legislativa je velmi benevolentní a nakládání s lidskými ostatky v podobě popela (na rozdíl od mrtvého těla) prakticky nijak neomezuje.

24 V zahraničí existují pohřební společnosti, které se specializují například na „pohřební“ plavby lodí za účelem rozptylu popela do moře (viz např́ílad Walter 1994). 
přítomnosti jeho těla nebo za přítomnosti jeho popela), zdá se, že větší část těch, kteří obřad nezajistí prostřednictvím pohřební služby, žádný kolektivní obřad neuskuteční. Výjimkou jsou věřící některých „nových“ náboženských skupin. ${ }^{25}$

Předpoklad nekonání žádného pohřebního obřadu podporuje i zkušenost $\mathrm{s}$ tím, jak pozůstalí zajištují obřady v pohřebních službách. Jejich přístup je většinou poměrně pasivní, objednávají pokud možno služby nevybočující z běžného schématu pohřbívání. Pro invenci a personalizovanější formy obřadů nemají příliš pochopení, k čemuž nepochybně přispívá i skutečnost, že pohřby podrobněji dopředu nepromýšlejí. Po smrti blízkého jsou pak pozůstalí v takovém psychickém rozpoložení, že nemají o „experimentování“ zájem a požadují především jednoduché a standardní postupy. Pracovníci pohřebních služeb tuto zkušenost reflektují a nesnaží se nabídku služeb rozšírit. Mnohdy ani sami nevnímají, že by obřad mohl mít jinou podobu a že by se v této oblasti dalo něco vylepšit. Rozšiřování nabídky chápou více materiálně, například jako možnost nabízet větší výběr květinové výzdoby, uren, případně i náhrobky atd. Trendy, které se dnes objevují v některých vyspělých a rovněž značně sekularizovaných státech Evropy, zejména v Nizozemí, ale částečně například i ve Velké Británii, v podobě personalizovaných a „do it yourself“ pohřbů do českého prostředí zatím nepronikly. Tyto novinky přitom vyžadují významné zapojení „laiků“ (at' již zesnulého před smrtí26 nebo pozůstalých) do př́pravy a prŕípadně i průběhu pohřebního obřadu. Domnívám se, že pozorovaná skutečnost, kdy se pozůstalí př́liš aktivně nepodílejí na pohřebních obřadech sjednávaných prostřednictvím pohřebních služeb, se ve velké míre replikuje i v soukromí, a přestože jistě existují výjimky, jsem přesvědčena o tom, že žádné speciální kolektivní pohřební obřady mimo pohřební služby nejsou konány. Systematický výzkum, který by na dostatečně velkém vzorku české populace potvrdil tuto domněnku, však zatím chybí.

\section{Preference pro sekulární, církevní nebo žádný pohřební obřad}

Vysvětlení absence pohřebních obřadů se budu věnovat dále $\mathrm{v}$ textu. $\mathrm{Na}$ tomto místě bych se ráda s použitím dat z české části šetření ISSP 2008 zabývala tím, jaké jsou preference lidí pro určitý typ pohřebního obřadu. Vzhledem $\mathrm{k}$ nabídnutým typům odpovědí to jistě pomůže dále ožrejmit fakt, že pohřbení bez obřadu se v české společnosti stává poměrně

25 Věřící některých specifických náboženských skupin si pohřební obřady zajišt’ují nezávisle na pohřební službě. V mém výzkumu tak činili Svědkové Jehovovi, kteří vlastní verzi pohřebního obřadu ve svých Sálech království (obdoba kostela) bez přítomnosti těla pro zesnulé konali vždy. V pohřební službě ovšem objednali pouze zpopelnění bez obřadu a nejčastěji žádali rozptyl popela. Členové náboženského Hnutí Hare Krišna zase považovali za ústřední obřady vykonávané před smrtí a v okamžiku smrti a dále zajišt'ovali pohřební obřady při rozptylu popela (realizovaného preferenčně do indických posvátných řek). (Př́imou zkušenost s realizací pohřebních obřadů dle pokynů Prabhupády měli ovšem pouze dva ze sedmi dotazovaných.) To jsou však př́iklady praktikujících věřících, jejichž zastoupení ve společnosti je malé a u kterých je absence pohřebních obřadů prakticky vyloučena.

26 Zatímco podrobné zpracování pohřebního plánu běžně nabízejí pohřební společnosti například v Nizozemí, Velké Británii či USA, ve zkoumaných českých pohřebních službách jsem se s touto možností nesetkala. 
běžnou volbou. Podívejme se tedy, kdo je preferuje nejčastěji a jaké jsou podíly osob přejících si sekulární, náboženský nebo raději žádný pohřeb z hlediska některých základních sociodemografických charakteristik. ${ }^{27}$

Nejprve se podívejme na vliv genderu (Tabulka 1). Bez ohledu na věk si v roce 2008 více než čtvrtina žen a necelá třetina mužů ze středních Čech ${ }^{28}$ přala být pohřbena s občanským obřadem. Další více než pětina žen si přála, aby byl součástí jejich pohřbu církevní obřad. Muži si oproti ženám přáli církevní pohřeb méně často, pouze $\mathrm{v}$ necelé desetině případů. Rozdíly na základě genderu se ukázaly výrazné i v tom, že muži byli výrazně častěji nerozhodní ohledně uspořádání vlastního pohřebního obřadu (38 \%), zatímco míra nerozhodnosti žen byla nižší ( $23 \%)$. Podíl osob, které si př́ly být pohřbeny bez toho, aby se konal smuteční obřad, byl naproti tomu vyrovnanější; jak mezi středočeskými ženami, tak mezi muži se jednalo o necelou jednu pětinu. Vyšší podíl žen volících církevní obřad přitom koresponduje $\mathrm{s}$ obecně větším zastoupením žen mezi věřícími, které není jen českou specialitou, ale platí takřka celosvětově (Hunt 2005, Hamplová a Řeháková 2009, Heelas a Woodhead 2005).

Tabulka 1: Preference pohřebního obřadu v souvislosti s genderem (v \%).

\begin{tabular}{|l|c|c|c|}
\hline Typ obřadu & Muž & Pohlaví & Žena \\
\hline & 8,4 & 21,8 & 14,5 \\
\hline Církevní obřad & 30,0 & 26,9 & 28,6 \\
\hline Sekulární obřad (občanský pohřeb) & 15,8 & 19,2 & 17,3 \\
\hline Pohřeb bez obřadu & 37,9 & 23,1 & 31,2 \\
\hline Je mi to jedno & 7,9 & 9,0 & 8,4 \\
\hline Neumím vybrat & 100 & 100 & 100 \\
\hline Celkem & 190 & 156 & 346 \\
\hline N & & & \\
\hline
\end{tabular}

Zdroj: ISSP 2008, respondenti ze Středočeského kraje a Prahy.

Další významnou souvislost ve sledovaných preferencích obyvatel středních Čech zjistíme, když zohledníme věk respondentů (Tabulka 2). Zatímco mezi respondenty pod 30 let bylo více než polovině osob jedno, jaký pohřební obřad by se pro ně konal, nebo se nedokázali pro některou z možností rozhodnout, většina respondentů na opačném konci věkové linie (nad 60 let) měla na věc utř́bený názor. Pouze zhruba čtvrtina osob starších šedesáti let neměla jasno $\mathrm{v}$ tom, jaký pohřební obřad by preferovala. Vcelku přirozeně začínají lidé s přibývajícím věkem rovněž zvažovat, jakým způsobem by chtěli být pohřbeni. Lidé starší

27 Pearsonův chí-kvadrát test odhalil statisticky významné rozdíly v preferencích typů pohřebních obřadů na hladině významnosti 0,001 dle všech uvedených charakteristik: gender, věk, náboženské vyznání a náboženská praxe, a to jak na uvedeném vzorku z oblasti středních Čech, tak celorepublikově (tato data zde neuvádím). Signifikantní byly též rozdíly při porovnání dle krajů (na hladině významnosti 0,001).

28 Termíny „střední Čechy“ a „středočeský“ použivám pro označení oblasti, ze které pocházeli respondenti a která v rámci současného administrativního územního dělení zahrnuje dva kraje: Středočeský kraj a Hlavní město Prahu. 
šedesáti let by si dnes ve středních Čechách nejčastěji přáli, aby byl pro ně uspořádán církevní pohřební obřad, a to ve více než třetině př́ípadů (38 \%). Podíly osob nad 60 let, které si přejí být pohřbeny se sekulárním obřadem nebo bez obřadu, byly poměrně vyrovnané a činily zhruba jednu pětinu. Pokud by dotazovaní nezměnili názor a pozůstalí jejich přání vyhověli, mohly by tyto podíly zhruba odrážet současnou praxi konání pohřebních obřadů s tím, že pro onu nevyhraněnou čtvrtinu by typ obřadu či jeho vypuštění zvolili pozi̊stalí.

Možný vývoj v konání pohřebních obřadů lze jen velmi zhruba odhadovat $\mathrm{z}$ aktuálních přání mladších věkových skupin, která jsou ovšem prozatím značně nevyhraněná a mohou se ještě výrazně proměňovat. Při vědomí těchto limitů se zdá, že pokud nenastane nějaký výraznější zvrat nebo změna preferencí ve prospěch vyššího ocenění náboženských obřadů, lze předpokládat, že se množství pohřbů zahrnujících církevní rituály bude ve středních Čechách poměrně výrazně snižovat. Mezi lidmi mladšími 30 let se totiž ve prospěch církevního obřadu vyjádřila pouze dvě procenta osob. Vzhledem $\mathrm{k}$ vyššímu počtu preferencí pro bezobřadné pohřbení ve věkové kategorii 45-59 let oproti lidem starším se zdá, že tento způsob pohřbení by se v několika prrístích desetiletích mohl ve středních Čechách ještě dále rozšiřovat.

Tabulka 2: Preference pohřebního obřadu dle věku ( $v$ \%).

\begin{tabular}{|c|c|c|c|c|c|}
\hline \multirow[t]{2}{*}{ Typ obřadu } & \multicolumn{4}{|c|}{ Věk } & \multirow[t]{2}{*}{ Celkem } \\
\hline & 18-29 let & 30-44 let & 45-59 let & 60 let a starší & \\
\hline Církevní obřad & 2,1 & 8,3 & 12,8 & 38,2 & 14,2 \\
\hline Sekulární obřad (občanský pohřeb) & 34,4 & 26,0 & 35,9 & 18,4 & 28,9 \\
\hline Pohřeb bez obřadu & 5,2 & 21,9 & 25,6 & 19,7 & 17,6 \\
\hline Je mi to jedno & 46,9 & 35,4 & 20,5 & 17,1 & 31,2 \\
\hline Neumím vybrat & 11,5 & 8,3 & 5,1 & 6,6 & 8,1 \\
\hline Celkem & 100 & 100 & 100 & 100 & 100 \\
\hline $\mathrm{N}$ & 96 & 96 & 78 & 76 & 346 \\
\hline
\end{tabular}

Zdroj: ISSP 2008, respondenti ze Středočeského kraje a Prahy.

Samotné přihlášení se $\mathrm{k}$ náboženské víré automaticky neznamená přání respondenta, aby byl pohřben s náboženským obřadem. Klíčová je zejména náboženská praxe, respektive účast na bohoslužbách (Tabulka 3). Pouze polovina respondentů, kteří se v šetření přihlásili k římskokatolickému či jinému křestanskému náboženskému vyznání, si prála, aby jejich pohřeb obsahoval náboženský obřad. Necelá jedna pětina osob hlásících se $\mathrm{k}$ nějakému křest’anskému vyznání si ve středních Čechách přála být pohřbena bez obřadu a další zhruba desetina si prála sekulární pohřební obřad. Zbytku na typu obřadu nezáleželo nebo na něj neměli vyhraněný názor. Lidé bez náboženského vyznání volili nejčastěji sekulární pohřební obřad, a to ve více než třetině př́ípadů ( $36 \%$ ), a v necelé pětině prípadů si přáli pohřbení bez obřadu. Zároveň jim bylo výrazně častěji než lidem věrícím jedno, zda a jaký obřad bude provázet jejich pohřbení (36 \% prŕmo uvedlo, že je jim to jedno a dalších $9 \%$ nedokázalo zvolit žádnou z nabízených možností) (Tabulka 3).

Výzkum naproti tomu potvrdil, že náboženská praxe a četnost návštěv bohoslužeb ovlivňuje volbu vlastního pohřebního obřadu mnohem výrazněji než deklarované náboženské 
vyznání. Čím častěji navštěvovali lidé bohoslužby, tím vyšší byla pravděpodobnost, že budou volit církevní pohřební obřad (Tabulka 3). Věřící křestané (ř́ímští katolíci i lidé hlásící se k jiným křest’anským vyznáním) navštěvující bohoslužby alespoň třikrát za rok si ve většině př́ípadů (v 7 prrípadech z 10) přáli církevní pohřební obřad (Tabulka 3). Naproti tomu lidé, kteří bohoslužby nikdy nenavštěvovali, by ani nechtěli mít církevní pohřeb. Téměř polovině osob (48 \%) nechodících nikdy na bohoslužby bylo jedno, jaký typ obřadu bude doprovázet jejich pohřbení (respektive tito respondenti nedokázali z nabízených možností vybrat), třetina si přála sekulární obřad, necelá pětina $(17 \%)$ by chtěla být pohřbena bez obřadu. Preference osob navštěvujících bohoslužby jen velmi zř́́dka - nanejvýš jednou či dvakrát za rok - jsou bližší lidem, kteří bohoslužby vůbec nenavštěvují, než lidem vykazujícím pravidelnější náboženskou aktivitu. Církevní obřad si přálo pouze $12 \%$ z nich. Pravidelná návštěva bohoslužeb tak mezi Středočechy zcela jednoznačně vede $\mathrm{k}$ volbě náboženského pohřbu konaného za př́itomnosti duchovního (at' již se koná v kostele, smuteční obřadní síni či jinde).

Tabulka 3: Preference pohřebního obřadu dle náboženského vyznání a dle náboženské praxe ( $\vee \%)$.

\begin{tabular}{|l|c|c|c|c|c|}
\hline Typ obřadu & \multicolumn{2}{|c|}{ Náboženské vyznání } & \multicolumn{3}{c|}{ Návštěva bohoslužeb } \\
\hline & $\begin{array}{c}\text { Ř́mskokatolické } \\
\text { či jiné křestanské }\end{array}$ & Žádné & Nikdy & $\begin{array}{c}\text { Maximálně 2x } \\
\text { za rok }\end{array}$ & $\begin{array}{c}\text { Minimálně 3x } \\
\text { za rok }\end{array}$ \\
\hline Církevní obřad & 49,5 & 2,0 & 2,3 & 12,3 & 72,3 \\
\hline $\begin{array}{l}\text { Sekulární obřad } \\
\text { (občanský pohřeb) }\end{array}$ & 9,9 & 35,8 & 33,0 & 34,2 & 4,3 \\
\hline Pohřeb bez obřadu & 17,6 & 16,5 & 17,0 & 24,7 & 10,6 \\
\hline Je mi to jedno & 17,6 & 36,2 & 38,1 & 23,3 & 6,4 \\
\hline Neumím vybrat & 5,5 & 9,4 & 9,6 & 5,5 & 6,4 \\
\hline Celkem & 100 & 100 & 100 & 100 & 100 \\
\hline$N$ & 91 & 254 & 218 & 73 & 47 \\
\hline
\end{tabular}

Zdroj: ISSP 2008, respondenti ze Středočeského kraje a Prahy.

Kvantitativní data umožňují postihnout specifika preferencí pro typ pohřebního obřadu podle jednotlivých regionů, v tomto prípadě krajů, České republiky. Můžeme tak začlenit oblast středních Čech, ve které byl prováděn kvalitativní terénní výzkum, do celorepublikového kontextu. Byly přitom odhaleny zjevné souvislosti mezi volbou pohřebního obřadu a místem bydliště (Tabulka 4).

Velké regionální rozdíly ve zjišt'ovaných preferencích ve prospěch náboženského obřadu souvisí nepochybně $\mathrm{s}$ vyšší religiozitou obyvatelstva některých oblastí, respektive $\mathrm{s}$ jejich častějším členstvím v církvích. Zatímco v severozápadní části České republiky se pouze zhruba jedna pětina obyvatel hlásila k nějakému konkrétnímu náboženskému vyznání, na druhém konci země, na jižní a východní Moravě, se k církvím a náboženskému vyznání hlásil podstatně vyšší podíl obyvatelstva. Podle údajů ze Sčítání lidu, domů a bytů 2001 to byly více než dvě pětiny, $\mathrm{v}$ oblastech podél hranic se Slovenskem dokonce více než polovina obyvatelstva. Náboženský obřad jako součást vlastního pohřbu by si prritom přál nejvyšší podíl obyvatel v následujících krajích: Zlínský (41%), Jihomoravský (33 \%), Vysočina 
(32 \%) a Jihočeský (31\%), tedy právě $\mathrm{v}$ oblastech $\mathrm{s}$ nejvyšším podílem věřících osob (Tabulka 4). Naproti tomu byl církevní obřad nejméně často volen obyvateli krajů s nízkým podílem věřících: v Plzeňském, Karlovarském a Ústeckém kraji si církevní pohřeb přál méně než každý desátý obyvatel. Sekulární pohřební obřady se ale zároveň těšily největší oblibě v kraji Jihočeském, v Praze, v Pardubickém kraji a také na Vysočině, kde se v jejich prospěch vyjádřilo více než $30 \%$ osob.

Zejména Jihočeský kraj, ale i Vysočina a v menší míre také některé moravské oblasti (Jihomoravský, Zlínský a Olomoucký kraj) byly specifické tím, že v nich lidé výrazně méně často chtěli být pohřbeni bez vykonání obřadu (což zvyšovalo podíl preferencí pro sekulární obřady). Vypuštění smutečního obřadu bylo naopak nejčastěji voleno v Plzeňském a Ústeckém kraji, kde si jej př́la zhruba třetina dospělých obyvatel. Kategorie ,je mi to jedno“ a „neumím vybrat“ vykazovaly při dělení dle krajů ohromný rozptyl, který poukazuje $\mathrm{k}$ možnému metodickému ovlivnění tazatelů jednotlivých regionů. ${ }^{29} \mathrm{Z}$ tohoto důvodu jsem se rozhodla posuzovat je dohromady. Výrazné bylo vysoké - více než dvoupětinové - zastoupení nerozhodnutých a nevyhraněných osob v Libereckém, Olomouckém, Středočeském a Karlovarském kraji. Nejnižší podíly osob s nevyhraněnými a nejasnými preferencemi zhruba čtvrtina a méně - byly naopak v kraji Vysočina a ve Zlínském kraji.

Tabulka 4: Regionální rozdíly v deklarovaných preferencích pohřebních obřadů ( $\vee$ \%).

\begin{tabular}{|c|c|c|c|c|c|c|c|}
\hline \multirow[b]{2}{*}{ Region (kraj) } & \multicolumn{5}{|c|}{ Preferovaný pohřební obřad } & \multirow[b]{2}{*}{$\begin{array}{c}\text { Celkem } \\
(\%)\end{array}$} & \multirow[b]{2}{*}{$\mathbf{N}$} \\
\hline & $\begin{array}{c}\text { Církevní } \\
\text { obřad }\end{array}$ & $\begin{array}{l}\text { Sekulární } \\
\text { obřad }\end{array}$ & $\begin{array}{c}\text { Pohřeb } \\
\text { bez } \\
\text { obřadu }\end{array}$ & $\begin{array}{c}\text { Je mi to } \\
\text { jedno }\end{array}$ & $\begin{array}{c}\text { Neumím } \\
\text { vybrat }\end{array}$ & & \\
\hline Praha & 13,3 & 32,8 & 16,1 & 31,1 & 6,7 & 100 & 180 \\
\hline Středočeský kraj & 15,1 & 24,1 & 19,3 & 31,3 & 10,2 & 100 & 166 \\
\hline Jihočeský kraj & 30,8 & 33,0 & 4,4 & 29,7 & 2,2 & 100 & 91 \\
\hline Plzeňský kraj & 8,9 & 15,2 & 36,7 & 35,4 & 3,8 & 100 & 79 \\
\hline Karlovarský kraj & 8,9 & 26,7 & 24,4 & 40,0 & 0 & 100 & 45 \\
\hline Ústecký kraj & 4,2 & 27,1 & 30,5 & 37,3 & 0,8 & 100 & 118 \\
\hline Liberecký kraj & 15,8 & 17,5 & 19,3 & 28,1 & 19,3 & 100 & 57 \\
\hline Pardubický kraj & 25,0 & 31,9 & 13,9 & 23,6 & 5,6 & 100 & 72 \\
\hline Královéhradecký kraj & 18,8 & 20,0 & 26,3 & 35,0 & 0 & 100 & 80 \\
\hline Vysočina & 32,4 & 31,1 & 10,8 & 24,3 & 1,4 & 100 & 74 \\
\hline Jihomoravský kraj & 33,1 & 19,9 & 12,7 & 31,9 & 2,4 & 100 & 166 \\
\hline Zlínský kraj & 41,2 & 25,9 & 12,9 & 17,6 & 2,4 & 100 & 85 \\
\hline Olomoucký kraj & 13,6 & 26,1 & 13,6 & 29,5 & 17,0 & 100 & 88 \\
\hline Moravskoslezský kraj & 18,1 & 25,4 & 24,9 & 28,8 & 2,8 & 100 & 177 \\
\hline Celkem & 19,8 & 25,7 & 18,9 & 30,4 & 5,2 & 100 & 1478 \\
\hline
\end{tabular}

Zdroj: ISSP 2008.

29 Tj. dostali odlišné instrukce o tom, kdy jednotlivé kategorie použít. Obě přitom neměly být respondentům nabízeny. 
Data ISSP ukázala aktuální preference týkající se pohřebních obřadů. Respondenti dotazovaní na to, jaký pohřební obřad by si pro sebe přáli, nejčastěji volili sekulární pohřební obřad (cca ve čtvrtině př́ípadů), a o něco méně často pak obřad církevní (cca v pětině př́ipadů). Jen nepatrně nižší frekvenci (pouze o jeden procentní bod) mělo pohřbení bez obřadu. Značné části populace (téměř třetině) bylo jedno, s jakým obřadem bude pohřbena (Tabulka 4). Tyto volby byly do určité míry ovlivňovány základními sociodemografickými charakteristikami. Středočeské ženy preferovaly jen o málo častěji sekulární pohřby před církevními, zatímco u středočeských mužủ byl rozdíl větší. Muži výrazně méně často stranili církevním obřadům a naopak oproti ženám výrazně častěji neměli na věc vyhraněný názor. Zájem o náboženské pohřební obřady byl nejvyšší v nejstarších věkových kategoríích a se snižujícím se věkem velmi výrazně klesal. Náboženské obřady samožrejmě preferovali věřící, jako mnohem důležitější než deklarované náboženské vyznání však byla identifikována aktivní náboženská praxe $\mathrm{v}$ podobě pravidelnějších návštěv bohoslužeb. Náboženské obřady si výrazně častěji práli také lidé žijící ve Zlínském, Jihomoravském, Jihočeském kraji nebo kraji Vysočina. Pro bezobřadné pohřbení se regionálně vyslovil nejvyšší podíl obyvatel (více než třetina) v Plzeňském kraji. Mužům, mladším lidem a nevěrícím bylo častěji než ostatním jedno, jaký pohřební obřad pro ně bude uspořádán.

\section{Aktérský pohled na význam pohřbu/pohřebního obřadu}

Pro hlubší pochopení voleb typů pohřebních obřadů i jejich záměrné nekonání je důležité vědět, jaký význam dnes lidé pohřbům/pohřebním obřadům ${ }^{30}$ připisují. To jsem se snažila zjistit $\mathrm{v}$ rozhovorech $\mathrm{s}$ informátory. Zmíním se nejprve o skupině těch, které zjednodušeně označuji jako „nevěřííi“, následně se budu věnovat praktikujícím věřícím.

Většina nevěřících $(21$ z 30$)$ vnímala pohřeb primárně jako rozloučení pozůstalých se zesnulým. Tento pohled kopíruje způsob, jímž je v současnosti pohřební obřad prezentován prostřednictvím „,parte“. Ta kromě oznámení úmrtí většinou uvádějí konání „posledního rozloučení“, nebo je užito sloveso „rozloučit se“ apod..$^{31}$ Také pracovníci pohřebních služeb slovo „rozloučení“ běžně užívají k označení pohřebního obřadu. Informátoři v odpovědích na otázku po smyslu či významu pohřbu často hovořili o „rozloučení“:

Já bych řekla, že je to rozloučení se vlastně s tím, naposledy rozloučení se s tím zesnulým. S tím, že vlastně mu zahraji jeho oblíbenou písničku. Já bych řekla, že je to asi poslední rozloučení. Kdy naposledy, než vlastně je biologicky pryč, bych řekla takhle asi. (Radmila, ředitelka domova důchodců)

No samozřejmě, ten člověk [zesnulý] už to neví, že mu někdo dělá pohřeb. Ale je to takové jakoby důstojné rozloučení s tím člověkem. Ř́kám, i když už to nevnímá. A je to i taková zažitá tradice. Že vlastně lidi se pohřbívají, že ano, v různých zemích jinak. Ale je to takové jakoby důstojné rozloučení s tím člověkem. (Lenka, kuchařka)

30 V rozhovorech byli aktéři tázáni na ,pohřby“, protože věřím, že je to termín lépe srozumitelný a neutrálnější než termín ,pohřební obřady“, který asi více implikuje souvislost s náboženskými obřady.

31 O rozloučení se zesnulým (bez uvedení místa a dne konání) se ovšem často píše i v případech, kdy se žádný pohřební obřad nekoná. 
Pohřeb byl tedy chápán především jako běžná forma rozloučení pozůstalých se zesnulým, přičemž nikdo z dotazovaných se nedomníval, že by jeho konání mělo dopad na př́ípadnou další existenci mrtvého. Pohřební obřady byly považovány především za záležitost, která má význam pro pozůstalé, i když to nemuselo automaticky znamenat, že všichni informátoři konání pohřbů vnímali pozitivně.

Jednoznačně kladný vztah ke konání pohřbů vyjádřilo jen několik informátorů. Oceňovali na nich především možnost symbolicky se rozloučit se zesnulým a prokázat mu tím jistou úctu, zavzpomínat na něj. Konání pohřebních obřadů popisovali v zásadě jako zažitou tradici, kterou je vhodné udržovat, především z úcty $\mathrm{k}$ zesnulému:

[Pohřeb] to je to poslední, kdy člověk může př́ímo vzdát [úctu] prostě tomu člověku nebo chtít se s ním jako rozloučit. To určitě, každopádně by to mělo být, nemělo by se to nikdy, já nevím, zrušit, určitě by to mělo probíhat dál. Určitě by to mělo. Takhle. Takže pohřby by se určitě měly konat. To je podle mě to, takové to opravdu nejdůstojnější rozloučení s tou osobou, která vám byla blízká, já nevím, přítel, kamarád, prostě to poslední rozloučení, které mu můžete symbolicky dát. (Radek, obchodni zástupce)

Kolektivní charakter pohřebních obřadů přitom explicitně zmínilo pouze několik nevěřících informátorů, což může znamenat, že ostatní jej bud’ považují za samožrejmý (a tedy nestojící za zmínku), nebo jej naopak nepřipomněli proto, že pro ně není důležitý. Dva informátoři př́mo uvedli, že pohřeb je jistým způsobem „divadlo pro lidi“, a přikláněli se spíše $\mathrm{k}$ jeho komornější variantě a realizování $\mathrm{v}$ úzkém rodinném kruhu, bez účasti veřejnosti. Několik informátorů př́mo terminologicky rozlišovalo mezi „pohřbem“, který chápali jako veřejně př́stupný, a „rozloučením“, které vnímali jako obřad určený pouze pro nejbližší pozůstalé. Jeden z nich činil tento rozdíl především proto, aby se mohl negativně vyjádřit $o$ veřejně př́stupných pohřbech oproti pozitivně chápaným rozloučením v úzkém kruhu rodiny a nejbližších přátel zesnulého. Dával přednost personalizovanější podobě obřadu, která nevyžaduje prrítomnost mrtvého těla a koná se $\mathrm{v}$ jiném prostředí než ve smuteční obřadní síni. Důraz kladl spíše na myšlenky a př́ípadně symbolickou blízkost zesnulému než na „zaběhaný“ obřadný průběh. Jeho výpověd’ celkem výstižně ilustruje myšlenkové posuny, které přispívají $\mathrm{k}$ nárůstu bezobřadného pohřbívání:

Aleš (IT odbornik): Já pohřeb beru jako společenskou povinnost. A kdyby bylo po mém, tak bych všechny pohřby zrušil. To mi právě přijde už takové zbytečné. Prostě bud'to toho člověka, na tom pohřbu se sejde spoustu lidí, kteří třeba dvacet let, třicet let toho člověka neviděli, vůbec si s ním nepsali, nevědí nic. Ted' dostanou parte a přijedou teda a co?

Tazatelka: Možná, že se tam vidí s nějakými jinými lidmi, které třeba vidí rádi?

Aleš: Ano, ale to se můžou sejít jinak, nemusejí se scházet na pohřbech, že ano? Takže já ty pohřby jako nemusím a mám na to ten názor, že to $\mathrm{k}$ ničemu vlastně není. Já bych bral spíš pohřeb v tom skutečném rozloučení, $v$ takovém tom užším kruhu rodinném. Ten, s kým se ten člověk pravidelně stýkal skutečně, a nemusí to, nemusí to být ani nad tou rakví. Prostě by se ti lidé měli sejít a říct no tak, vzpomínáme, takový a takový život to byl a žil ten člověk dobrý život nebo žil špatný život a budeme na něj vzpomínat v dobrém. Anebo se klidně sejít u někoho doma, anebo se sejít někde $\mathrm{v}$ hospodě s prominutím, ale to je podle mě daleko významnější než někde v obřadní síni. Zástup príbuzných, který se dlouho, dlouho neviděli. 
Podobné postoje nebyly mezi středočeskými neveřrícími informátory ojedinělé. Přestože se našli i zastánci pohřebních obřadů konaných za účasti širší veřejnosti, pro nikoho nebyla účast velkého množství lidí na pohřbu ústřední záležitostí. Nikdo z informátorů také př́ímo neodsuzoval rozhodnutí pozůstalých uspořádat rozloučení se zesnulým pouze v úzkém rodinném kruhu. Několik informátorů se přiznalo, že se účasti na pohřbech spíše vyhýbají, pokud to jde. I ti však jistý smysl v pořádání pohřebních obřadů pro nejbližší př́ibuzné většinou spatřovali. Dva nevěřící informátoři (z třiceti) ovšem považovali realizování pohřebních obřadů $\mathrm{v}$ současné české společnosti za zcela zbytečné a přímo uvedli, že $\mathrm{v}$ tomto počínání nevidí žádný smysl.

Pohledy veřících z křest’anských církví (římskokatolické, českobratrské evangelické a Svědků Jehovových) většinou nebyly zásadně odlišné od pohledů nevěrící majority, alespoň co se týkalo výpovědí o významu přikládanému pohřbu. I oni jej spojovali především s pozůstalými, nikoliv se zesnulým. Př́ślušnost ke konkrétní náboženské skupině se však do jejich vnímání promítla. Oproti neveřícím konání pohřebních obřadů častěji hodnotili kladně (s výjimkou Svědků Jehovových). Také mezi věřícími křest’any 32 se ovšem občas vyskytovala kritika velkých pohřbů, i oni často dávali přednost minimalizaci pohřbů, a to jak po stránce ceremoniální, tak co se týká počtu účastníků. Podobně jako nevěřící chápali pohřeb nejčastěji jako rozloučení, zejména v př́padě ř́mských katolíků. Protestanti z Českobratrské církve evangelické zdůrazňovali dále jeho význam pro smírení se se smrtí blízkého a podporu pozůstalých a podobně tomu bylo i u Svědků Jehovových, jejichž vzpomínková slavnost ${ }^{33}$ připomíná pozůstalým zesnulého a naději na vzkříšení.

Římští katolíci nejčastěji poukazovali na pozitivní význam pohřebních obřadů. Kladně hodnotili jak zažitou tradici, tak možnost využít celospolečensky uznávanou formu projevu smutku. Př́ikladem může být následující citace:

Pohřební rituál mám opravdu ráda. Já myslím, že pomáhá lidem truchlit, jako strukturovaně truchlit, a vůbec tomu dává nějakou formu. Že je to nějaká jakoby společensky uznávaná forma, kam to patř́, kam člověk všechny emoce, které jsou s tím spojené, může vkládat, a mám pocit, že je to veliká věc. (Eva, katolička, psycholožka $)^{34}$

Podobně protestanti z ČCE často hovořili o významu pohřbu pro pozůstalé jako o možnosti vyrovnat se se smrtí blízkého. Absenci pohřebního obřadu pak vnímali spíše negativně a považovali ji za jednu z př́ícin prodloužení období truchlení po smrti blízkého. Pozitivně někdy hodnotili i kolektivní charakter pohřbu podporující rodinnou soudržnost. Katolíci i protestanti dále poukazovali na liminální charakter pohřbu, ${ }^{35}$ vnímali jej jako „konec etapy žití s člověkem“, „uzavření kapitoly“ či „ohraničující složku“:

32 Termín „křest’an“ zde používám zjednodušeně pro označení informátorů praktikujících a hlásících se k jedné ze tří zkoumaných náboženských skupin: římským katolíkům, protestantům ČCE či Svědkům Jehovovým. Důležitý je pro mě aktérský pohled, tedy křest’anská sebeidentifikace.

33 Vzpomínková slavnost je variantou pohřebního obřadu, koná se v Sále Království bez přítomnosti těla zesnulého.

34 Toto hodnocení souviselo se vzděláním a profesionální zkušeností informátorky - psycholožky.

35 Liminální charakter pohřbů a dalších přechodových rituálů zdůrazňovali např́iklad Gennep (1997) a Turner (2004). 
...pohřeb je právě takovou ohraničující složkou nebo takovým určitým zářezem v tom loučení s tím blízkým. Ještě navíc, když se setkají lidé, př́ibuzní a mohou to prožít spolu, mohou se rozloučit spolu, tak to je pro ně velmi důležitý a nezbytný krok k tomu vyrovnání. To vyrovnání může přijít až po tom truchlení. Takže myslím, že tam, kde se tomu lidé vyhnou, pohřeb se nekoná a nezpracují to, tak se jim to vrací mnohem déle. (Anna, evangelička, asistentka $v$ hospici)

Náboženské pohřby však mají navíc ještě jednu důležitou rovinu, kterou ovšem zmiňovali především duchovní. Ti vedle důstojného rozloučení se zesnulým neopomněli připomenout transcendentní rovinu a odkaz na posmrtnou existenci. Katolický kněz v této souvislosti upozornil na výprosnou hodnotu (zádušní) modlitby, kterou mohou pozůstalí díky Kristově oběti na kř́ži vykonávat pro zemřelé:

Dobro, to znamená věčné štěstí, věčný život. A to jsou ty naše modlitby, jinými slovy, to jsou ty poslední květiny na ten hrob. Kdy tedy člověk děkuje za život toho člověka, což je prrirozené, něco hezkého jsme s ním prožili, a prosí za spásu jeho nesmrtelné duše. (Pavel, katolický kněz)

Modlitby za zemřelého a zádušní mše, které jsou tradiční součástí katolického pohřbu (ač již dnes poněkud opomíjenou a často konanou v jiném časovém období než pohřbení těla), byly vnímány jako prostředky, které měly pomoci duši zemřelého $v$ její další existenci (odstranit či zmírnit očistcová muka před posledním soudem). Kromě kněze však tento význam pohřebních obřadů nikdo v rozhovoru nepřipomněl. I kněz samotný se zmínil, že byl po příchodu do pražské farnosti překvapen, že „lidé nespojují to rozloučení toho člověka [pohřeb] s tou zádušní mší“. Žádají o zádušní mši např́iklad až poté, co již proběhla kremace, někdy třeba i půl roku po úmrtí. Na venkově byla podle jeho zkušenosti situace jiná a loučení s tělem mrtvého bylo s konáním zádušní mše více časově provázané.

Farář ČCE poukázal na další funkci pohřbu, a sice symbolické svěření mrtvého Bohu. Tu podle jeho přesvědčení přesně vyjadřuje modlitební formule pronášená během pohřbu:

Věčný Bože, tobě poroučíme (nebo odevzdáváme) sestru tu a tu (bratra toho a toho) v jisté a pevné naději odpuštění a vzkříšení k životu věčnému skrze Krista, našeho Pána. (Jan, evangelický farár)

Další důležitý význam pohřbů, ovšem toliko církevních, spatřovali někteří věřící (explicitně ho zmínili dvě evangeličky a dva Svědkové Jehovovi) v transcendenci smrti a zprostředkování naděje na další existenci. Hovořili o tom, že během církevního pohřbu jsou přítomní ujišt'ováni, že „to nekončí tou smrtí, ale že pak přijde vzkříšení“. Ač nebyl tento význam pohřbu věřícími během rozhovorů př́liš často připomínán, jedná se o zásadní rozdíl, který by církevní pohřby měly mít oproti sekulárním pohřbům.

Pokud věřící negativně hodnotili pohřební rituály, pocházeli většinou z řad Svědků Jehovových nebo oddaných Krišny. Specifické pro ně bylo, že nekritizovali vlastní zvyky, ale zvyky jiných skupin věŕících nebo nevěřící majority.

Základní významy přikládané pohřbům se tedy při porovnání zkoumaných věřících a nevěřících s výjimkou křest’anských odkazů ke vzkříšení nijak zásadně nelišily. Obě skupiny spojovaly hlavní význam uspořádání kolektivního pohřebního obřadu s pozůstalými 
a jejich symbolickým loučením se zesnulým ${ }^{36}$ Pohřby a pohřební obřady byly nejčastěji chápány jako (důstojné) rozloučení se zesnulým. Někteří lidé (nejčastěji římští katolíci) je vnímali jako prostředky urychlující proces truchlení a vyrovnání se se smrtí, jiní (většinou Svědkové Jehovovi, př́ipadně evangelíci) oceňovali, že je př̌ nich připomenuta naděje na vzkřrišení. Pozitivně vnímali pohřby nejčastěji věřící katolíci a evangelíci, ale kladně je hodnotila i část nevěřících. Věřící „nových“ náboženských skupin (např́iklad Svědkové Jehovovi) často kritizovali a odsuzovali způsob, jakým provádějí pohřební obřady ostatní.

\section{Absence pohřebního obřadu}

Jednou z nejspecifiččějších záležitostí současné české pohřební praxe je nekonání kolektivních pohřebních obřadů; $\mathrm{k}$ jeho rozšiřrení přitom došlo během posledních dvaceti let.

Ze sociálního a historického hlediska je volní rozhodnutí neuspořádat pro mrtvého (aniž by byl zločincem, jinověrcem nebo jinak závažně sociálně vyloučenou osobou) v době míru a prosperity žádný pohřební obřad více než ojedinělé. Jaké okolnosti a důvody tedy vedou $\mathrm{k}$ rozšiř̌ení této praxe $\mathrm{v}$ české společnosti? Výše uvedený rozbor kvantitativních dat naznačuje, že významnou úlohu hraje, mimo jiné, vysoká míra sekularizace. Jen menšina lidí dnes volí církevní pohřební obřady a nevěřícím je častěji jedno, zda a jaký pohřební obřad se pro ně bude konat. Jednoduché sekulární pohřební obřady, které se mohutně rozšíríily $\mathrm{v}$ době komunistické vlády, se však od politického převratu konají stále méně často. Pro mnohé je lepší variantou nepořádat žádný obřad. Důvod pro to jistě není jediný, stejně jako nejde pouze o důsledek sekularizace, jak naznačuje skutečnost, že $\mathrm{v}$ jiných sekularizovaných státech se pohřební obřady stále konají (navíc většinou dokonce církevní). Lze rozlišit tři typy faktorů, které nepochybně přispívají $\mathrm{k}$ rozhodnutí nekonat žádný pohřební obřad: ekonomické, psychologické a sociální. Všechny se přitom mohou uplatnit ve dvou explanačních rovinách - aktérské a analytické. ${ }^{37}$

Aktérské výklady tohoto jevu byly poměrně jednoznačné. Jako hlavní důvod nekonání pohřebních obřadů uváděli informátoři nejčastěji vysokou nákladnost pohřbů, tedy faktor ekonomický. Ač byly finanční náklady často zmiňovány na prvním místě, zjevně nejsou jediným důvodem. Informátoři, kteří pohřební obřady pro své blízké konali, pak rovněž věřili, že

36 Odlišnější pohled mají př́islušníci některých malých náboženských skupin, ve zkoumaném vzorku to byli oddaní Krišny. Jejich symbolický svět i denní praxe jsou ovšem natolik speciální, že by bylo nutné jim věnovat samostatný článek. Podobně tomu je i s některými imigrantskými skupinami, především v prrípadě odlišného náboženského zázemí. V západní Evropě, která má dlouhodobější zkušenosti s imigranty, je právě jim připisována zajímavá úloha rozšiřování možností konání pohřebních obřadů, nebot' pohřební služby byly nucené zvětšit svoji nabídku, aby uspokojovaly i jejich specifická přání (Howarth 1996). V českém prostředí jsem doposud takové změny nezaznamenala.

37 Ve shodě s interpretativní sociologií L. Holého a M. Stuchlíka považuji obě roviny za důležité, proto pojednávám jak o tzv. ,folk models“, tedy aktérských výkladech, tak také o ,anthropological/ sociological/psychological models“, tedy analytických nebo interpretativních konstruktech, které jsou na nich založené (Holy a Stuchlik 1981). 
neuspořádání veřejného pohřbu ještě neznamená naprostou absenci jakéhokoliv kolektivního pohřebního obřadu.

Já si stejně myslím, že ti lidé [pozůstalí] se asi třeba nějak sejdou doma a zapálí svičku a prostě posedí. Já nevím. Zavzpomínají. Myslím si to aspoň. Neodsuzuji to. Tak každý, že ano, dneska je to i hodně o financích. Takže to [nekonání pohřbu] neodsuzuji. Já si myslím, že každý člověk se sám podle sebe rozloučí s tím člověkem. At' už prostě, když už se o tom mluví, nebo sám v sobě. Takže jako neodsuzuji. To si myslím, že je každého věc... To asi taky hodně záleží na tom, jak třeba ten člověk, jaký žil ten člověk život, protože naše babička měla hodně známých, a tak jsme si říkali, že by to asi bylo takové hloupé, že prostě si myslím, že spousta lidí na ten pohřeb chtělo jet. Takže $\mathrm{z}$ toho důvodu. A když by to třeba byl člověk, který spíš byl uzavřený a nechodil moc do společnosti, tak si myslím, že ten pohřeb je v podstatě zbytečný. (Kamila, grafička)

Uvedená citace poukazuje na další důležité sociální souvislosti. Tolerance $\mathrm{k}$ pořádání pohřebních obřadů pouze pro úzký kruh pozvaných nejbližších byla ve zkoumaných lokalitách středních Čech velmi vysoká. V př́padech takovýchto soukromých obřadů nemají ovšem vzdálenější osoby prakticky množnost zjistit (ani nijak kontrolovat), zda se nějaký kolektivní obřad (at' již organizovaný prostřednictvím pohřební služby či nikoliv) uskutečnil nebo ne, a co je možná ještě důležitější, ani o to neusilují. Dalším sociálním faktorem jsou reálné sociální kontakty osoby před smrtí. Ty berou pozůstalí v potaz, když se rozhodují, jaký pohřební obřad uspořádají. Omezené sociální kontakty přispívají k rozhodnutí pro skromnější variantu obřadu nebo dokonce $\mathrm{k}$ volbě bezobřadného pohřbení.

Informátoři, kteří se rozhodli neuspořádat pohřební obřad pro své blízké, zmiňovali především velké psychické zatížení, které by pro ně pohřební obřad údajně znamenal. Neuspořádání pohřebního obřadu bylo aktéry interpretováno jako strategie vyhnutí se silným emocím a vzpomínkám na zesnulého, které by podle jejich soudu byly evokovány během kolektivního pohřebního obřadu. Faktor psychologický tak pro ně byl (alespoň rétoricky) jednoznačně důležitější než faktor ekonomický. Informátorka, která pro svoji matku (zesnulou zhruba v padesáti letech na rakovinu) pohřební obřad nezajistila, popisovala svoji zkušenost následovně:

Zažila jsem pohřeb, který teda jsme udělali u mé mámy, že jsme jí nechali spálit bez obřadu. A potom jsme šli jenom tu urnu uložit. Protože jsme neměli sílu na to, abychom dělali nějakou sešlost a tam to probírali s lidmi. My jsme to nedokázali... Protože to bylo pro nás hrozně těžké, protože jsme všichni byli tak psychicky na dně z toho, co se stalo, že jsme byli rádi, že jsme vůbec vyřídili takové ty formality. A vím, samozřejmě, že nám to spousta lidí zazlívalo, že se nemohli rozloučit, ale my jsme na to neměli vlastně ani peníze a hlavně jsme na to neměli odvahu. My jsme věděli, že bychom se tam sesypali všichni a v podstatě jsme byli tři sourozenci a takhle jsme se domluvili, že to takhle bude. A takže jsme nevěděli, kdy ji spálili, ale přišlo nám oznámení a já a sestra, tak jsme si došly pro urnu a tam jsme teda nechaly toho hrobníka, aby tu urnu [uložil na hřbitově]... Takže tam jsme ji uložily, no a pak jsme šly do cukrárny na kafe. Povídaly jsme si o tom ještě a ještě jsme si říkaly, že se nám ten hřbitov nelíbí. No a to bylo naše rozloučení. My jsme se s ní rozloučili v podstatě každý sám a v duchu. (Markéta, masérka)

Analytické interpretace nekonání pohřebních obřadů zohledňují širší sociokulturní kontext dané situace. Významným psychologickým faktorem působícím ve prospěch rozhodnutí 
nepořádat žádný pohřební obřad je nepochybně skutečnost, že podoby současných (sekulárních) obřadů neuspokojují psychické potřeby pozůstalých. Smysl sekulárních pohřebních obřadů zavedených za komunismu, kdy byla vyzdvihována osobnost mrtvého a jeho práce pro socialistickou společnost, se vytratil. Tradiční křest’anské obřady se pak konají málo vinou nízkého zastoupení aktivních věrících ve společnosti, která je navíc zasažená značnými proticírkevními tendencemi (viz Nešpor 2004, Nešporová a Nešpor 2009). A nové smysluplné formy ${ }^{38}$ sekulárních obřadů nevznikly. Na aktérské úrovni navíc prakticky chybělo (především mezi nevěrííími) ocenění pohřebních obřadů jakožto vyjádření podpory nejbližším pozůstalým, obvyklý byl spíše opak. $\mathrm{V}$ reálné praxi se to projevovalo i odmítáním kondolování po skončení obřadu či právě konáním soukromých (tj. neveřejných) pohřebních obřadů. $\mathrm{K}$ tomu přistupuje další psychologický faktor, totiž to, že zkoumané pohřební ústavy se z různých důvodů nesnažily svým klientům cíleně poskytovat emocionální podporu. Tu ostatně ani nevnímali, na rozdíl od pracovníků pohřebních služeb jinde ve světě, jako důležitou charakteristiku obřadu. ${ }^{39}$

Další klíčové faktory můžeme označit jako sociální, případně kulturní. Zmíněna byla ve stř̌edních Čechách zjištěná vysoká míra akceptace neveřejného konání pohřebního obřadu, respektive běžné konání obřadu pouze pro zvané, tj. nejužší rodinu a nejbližší přátele zesnulého. Pozdní modernita vedla $\mathrm{k}$ nárůstu individualizace (členů) společnosti (Beck 2004, Singly 1999, Bauman 2004), jejímž důsledkem je pokles sociální provázanosti jedinců. Význam lokálních komunit pro většinu lidí poklesl ruku v ruce s úpadkem počtu kolektivních aktivit konaných $\mathrm{v}$ rámci určitých společenství či skupin, včetně kolektivních obřadů, pohřební nevyjímaje.$^{40} \mathrm{Smrt}$ se výrazně privatizovala a i pohřební obřady se stále častěji stávají pouze rodinnou záležitostí uzavřenou př́stupu širší veřejnosti. Také sociální tlak působící ve prospěch uspořádání veřejného pohřbu značně ustoupil.

Důležitým sociodemografickým faktorem hodným zmínění je prodlužující se délka lidského života (ČSÚ 2010). Ta má různé dopady, včetně toho, že často přináší sociální izolaci seniorů v posledních letech života (Elias 1998, Sudnow 1967). S vysokým věkem dožití souvisí i skutečnost, že většinou žije jen málo vrstevníků a ještě méně takových, kteří by byli vzhledem ke svému zdravotnímu stavu schopni pohřeb navštívit. Umírají ponejvíce důchodci, takže okruh možných účastníků pohřbu je dále zmenšen o pracovní kolegy. Sociální izolace před smrtí a během umírání tak $\mathrm{v}$ jistém smyslu přirozeně pokračuje i po smrti v podobě nekonání kolektivního pohřebního obřadu.

Ekonomický faktor byl často zmiňován nejen $\mathrm{v}$ rozhovorech $\mathrm{s}$ informátory, ale jeho role bývá vyzdvihována i v médiích i v odborné literatuře (viz Haškovcová 2000: 94).

38 Zde mám na mysli personalizované obřady šité na míru osobnosti a požadavkům pohřbívaného a pozůstalých (viz např́klad Walter 1990, Willson 1990, Wienrich a Speyer 2003).

39 Emocionální podpora byla pozůstalým tradičně poskytována církevní komunitou, $v$ sekularizovaných společnostech ji na sebe mnohdy převzaly právě pohřební společnosti (viz např́klad Schäfer 2005; Venbrux, Perlen a Altena 2009; Walter 1990).

40 Oproti tomu narostl počet kolektivních akcí, jejichž účastníci se vzájemně neznají, ale vyhledávají společné prožitky (např́klad koncerty, sledování sportovních utkání atd.). Mezi ty lze zařadit i masové vzpomínkové akce, kdy po tragické smrti známých osobností lidé přinášejí na veřejná místa květiny, svíčky a další věci k uctění památky zemřelých (Walter 1999, Grider 2006). 
Nepochybně však není jediným a ani ne nejdůležitějším faktorem, který nekonání pohřebních obřadů způsobuje. Už proto, že ceny pohřbů nejsou v ČR oproti jiným zemím, v poměru k platům, nijak výrazně vyšší, spíše naopak. ${ }^{41}$ Podobné (relativně nízké) finanční náklady na pohřeb, tedy zhruba tři čtvrtiny průměrného měsičního platu, jsou běžné např́íklad ve Velké Británii (Walter 1990: 78, Wienrich a Speyer 2003: 84). Jak ovšem zdůrazňuje T. Walter, obavy z vysokých cen pohřbů, značně rozšířené i v Británii, nesouvisí s jejich reálnou cenou. $\mathrm{V}$ mnohých společnostech byly a jsou na pohřby běžně vynakládány mnohem vyšší částky bez toho, aby se nad tím někdo pozastavoval. Někdy dokonce platí, že chudší skupiny společnosti naopak pořádají nákladnější pohřby (Walter 1990: 75-88). V českém prostředí jsou takovým př́padem Romové, ale určitě by se našly i další př́iklady.

Ve společnosti, kde lidé jen výjimečně věrí, že by vykonání pohřebního obřadu mohlo nějak ovlivnit posmrtnou existenci zesnulého, a kde zároveň mnoho lidí nepocit’uje závazek uspořádat pohřební obřad pro pozůstalé nebo jako vyjádření úcty $\mathrm{k}$ zesnulému, se zákonitě množí prípady, kdy pohřební obřad zcela absentuje. Zmíněné faktory samožrejmě v praxi působí dohromady a vzájemně se posilují.

\section{Závěr}

Česká společnost je ve vztahu ke smrti celosvětově specifická tím, že výrazným způsobem omezila vliv náboženských představ a zvyků na zacházení se smrtí. I ve značně sekularizovaných společnostech (například v západní Evropě) si církve totiž obvykle podržely právě funkci spojenou s pohřbíváním mrtvých, kterou britská socioložka G. Davie dává do širšího kontextu tzv. zástupné (vicarious) funkce církví na konci 20. století (Davie 2000). V české společnosti je naproti tomu tato funkce značně oslabená. Příčiny ovšem musíme hledat hlouběji než jen $\mathrm{v}$ proticírkevních postupech uplatňovaných komunistickou vládou během druhé poloviny 20. století, již proto, že $\mathrm{v}$ jiných státech postkomunistického bloku (např́klad v Polsku, Rumunsku, na Slovensku) jsou dodnes náboženské pohřby normou, a naopak $\mathrm{v}$ české společnosti se podobné tendence, třebaže $\mathrm{v}$ zastř̌enější podobě a $\mathrm{s}$ nižší četností, uplatňovaly již před nástupem komunistického režimu. Tím ovšem nemá být zpochybněna skutečnost, že současný stav pohřbívání $v$ české společnosti výrazně navazuje na dřívější praxi, zejména $\mathrm{v}$ př́padě četnosti a průběhu konání sekulárních pohřebních obřadů.

Data ISSP 2008 přinesla zajímavé poznatky o preferencích české populace stran pohřebních obřadů. Zhruba čtvrtina Čechů si přeje sekulární pohřební obřad, pětina obřad církevní a zhruba další pětina si přeje být pohřbena bez obřadu. Zbytku společnosti je jedno, jaká $\mathrm{z}$ těchto možností bude provázet jejich pohřbení. Odnáboženštění významné části českého pohřbívání se tedy odrazilo ve formách konání pohřebních obřadů, včetně jejich minimalizace či dokonce úplného zrušení. Mohutné rozšiřrení sekulárních pohřebních obřadů, k němuž

41 V roce 2006 se běžná cena za pohřeb s obřadem (kremací či uložením do země) pohybovala zhruba mezi 12 až 25 tisíci Kč (nepočítaje náklady na hrob či uložení urny na hřbitově). Průměrný plat přitom činil v roce 2006 zhruba 20 tisíc Kč, a v té době byla ještě všem pozůstalým zajištujícím pohřbení v ČR k dispozici plošná sociální dávka „pohřebného“ ve výši 5 tisíc Kč (od roku 2008 je určena pouze nezletilým dětem pohřbívajícím rodiče či rodičům pohřbívajícím nezletilé děti). 
došlo během vlády komunistického režimu, spolu s dalšími společenskými okolnostmi vedly během posledních dvaceti let $\mathrm{k}$ dalšímu posunu, $\mathrm{k}$ omezení $\mathrm{v}$ konání pohřebních obřadů a $\mathrm{v}$ některých př́padech dokonce $\mathrm{k}$ jejich naprosté absenci. Vzhledem $\mathrm{k}$ nízkému zastoupení věřících $\mathrm{v}$ české populaci není totiž př́liš rozšiřrený tradiční společenský závazek $\mathrm{k}$ vykonání náboženského pohřebního obřadu, zatímco sekulární ceremonie podle některých autorů vykazují v porovnání s těmi náboženskými menší závaznost a jsou spíše věcí volby, nikoliv povinnosti (viz Chlup 2005: 192). I tato charakteristika pomáhá objasnit rozšírení nového jevu nekonání žádného kolektivního pohřebního obřadu, které bylo zaznamenáno při výzkumu ve středních Čechách. Přestože sekularismus a komunismus nepochybně ovlivnily historický vývoj pohřebních obřadů, objasňují současné dění jen částečně. Pro rozšiření interpretačního rámce zkoumané problematiky může být ústřední role identity.

V historické perspektivě souvislostí pohřebních obřadů $\mathrm{v}$ evropském či západokřest’anském kontextu je klíčová proměna od věčného, eschatologického naplňování identity k vnitřnímu, retrospektivnímu naplňování identity, na kterou upozornil britský sociolog a teolog $\mathrm{D}$. Davies (2007). Křest’anská věrouka v minulosti kladla důraz na posmrtný život a vzkříšení, přičemž tento aspekt se samozřejmě promítal i do konání pohřebních obřadů. Smrt byla překonávána odkazem $\mathrm{k}$ dalšímu budoucímu dění a identita zesnulého tak nebyla smrtí uzavřena, nýbrž byla vztažena k posmrtné existenci, poslednímu soudu i naději na (tělesné) zmrtvýchvstání. V současných západních společnostech dochází k proměně tohoto vnímání a postupně nabývá na významu tzv. retrospektivní identita, lépe korespondující s privatizovaným a konzumeristickým nastavením sociokulturního prostředí. Identita mrtvého je v podstatě uzavírána smrtí a následnými pohřebními obřady, během kterých je rekonstruována $\mathrm{v}$ podobě odkazu na život zesnulého. Zatímco v minulosti byla identita dotvářena „futuristickými“ hledisky, současná společnost dává přednost pohledu do minulosti. $V$ západních společnostech se tento posun odráží v rozšiřování tzv. personalizovaných pohřbů, kladoucích důraz na osobnost zesnulého a jeho život. Poptávka po takových obřadech je veliká a postupně se jí přizpůsobují i církve, takže personalizované pohřby rozhodně nemusí být sekulární, ale často jsou zároveň náboženské (Garces-Foley a Holcomb 2006, Quartier 2009).

Český př́ípad je ovšem poněkud odlišný. Zatímco v západní Evropě se nehledě na postupující sekularizaci pohřby dlouho odvíjely na církevní bázi a místo na osobnost zesnulého se zaměřovaly na Boha a teprve zhruba $v$ posledních dvaceti letech se nově prosazují personalizované pohřby, $\mathrm{v}$ českém prostředí můžeme sledovat spíše opačný trend. Personalizovanější formy pohřebních obřadů zaměřené na život zesnulého se v ČR v rámci sekularizovaných a občanských pohřbů uplatnily v porovnání se západní Evropou dříve, zatímco v současnosti dochází $\mathrm{v}$ některých aspektech spíše $\mathrm{k}$ jejich utlumení. Personalizace, při pohřebním obřadu zajištovaná nejčastěji smutečním proslovem prripomínajícím život a osobnost zesnulého, případně využitím symbolů spojených s osobností mrtvého, se z pohřebních obřadů, alespoň ve středních Čechách, spíše vytratila. Na vině je především redukce řečové složky obřadu. Lze tuto skutečnost interpretovat tak, že není třeba nijak kolektivně rekonstruovat a uzavř́ít identitu mrtvého prostřednictvím obřadu?

Ve prospěch kladného zodpovězení této otázky by svědčila skutečnost, že pro část mrtvých není žádný kolektivní obřad pozůstalými zorganizován. Možná si mnozí Češi identitu nepotřebují prostřednictvím pohřebního obřadu utváret, je pro ně uzavřena už samotnou 
smrtí. Stávající forma sekulárního obřadu ji navíc budovat vlastně ani nepomáhá. Zároveň ale nebuduje ani identitu vztaženou do budoucna, tedy eschatologickou. Samotné rozloučení, které bylo většinou středočeských informátorů (at' již věřících nebo nevěřících) zmiňované jako hlavní význam pohřbu, lze potom provést zcela individuálně a soukromě, bud' ve spojitosti s nějakým aktem (např́íklad zapálením svíčky, vystavením fotografie atd.) nebo pouze v myšlenkách každého z pozůstalých. Pokud není společenský rozměr pohřebního obřadu vnímán aktéry jako důležitý a zároveň není pocit’ována potřeba kolektivně rekonstruovat a uzavř́ít identitu zesnulého, pak ztrácí pořádání pohřebního obřadu význam. Není-li zároveň pocitován závazek vůči zesnulému, ostatním pozůstalým nebo sociálnímu okolí pohřeb uspořádat, pak může být skutečně vnímán pouze jako zbytečné vydání finančních prostředků, které mohou být využity jinak. Nejde tedy primárně o cenu, ale spíše o priority a preference spotřebitelů při výběru (různého) zboží a služeb na trhu, na němž funerální záležitosti stojí zcela v pozadí, aniž by podle názoru většiny svým významem překračovaly pouhou „technickou“" rovinu likvidace tělesných ostatků. ${ }^{42}$

\section{Literatura}

ADAM, Adolf. Liturgika. Křest'anská bohoslužba a její vývoj. Praha: Vyšehrad, 2001. 471 s. ISBN 80-7021-420-1.

ARIÈS, Philippe. Western Attitudes toward Death: From Middle Ages to the Present. Baltimore and London: The Johns Hopkins University Press, 1976, 111 s.

BABIČKA, Václav. Vývoj katolické religiozity v Českých zemích v letech 1949-1989 (na základě zjištování Státního úřadu pro věci církevní a Ministerstva kultury - sekretariátu pro věci církevní). Sbornik archivnich prací, 2005, č. 2, s. 379-506. ISSN 0036-5246.

BAUMAN, Zygmunt. Individualizovaná společnost. Praha: Mladá fronta, 2004. 290 s. ISBN 80-204-1195-X.

BECK, Ulrich. Riziková společnost. Na cestě k jiné moderně. Praha: Sociologické nakladatelství, 2004. 431 s. ISBN 80-86429-32-6.

BERGER, Peter L.; LUCKMANN, Thomas. Sociálni konstrukce reality. Pojednání o sociologii vědění. Brno: Centrum pro studium demokracie a kultury, 1999. 214 s. ISBN 80-85959-46-1.

CRESWELL, John W.; PLANO CLARK, Vicki L. 2007. Designing and Conducting Mixed Methods Research. London: Sage, 2007. 274 s. ISBN 978-1-4129-2792-5.

ČSÚ. Demografická přiručka 2009. Praha: Český statistický úřad, 2010 (online, dostupné z: <http:// www.czso.cz>).

DAVIE, Grace. Religion in Modern Europe. A Memory Mutates. Oxford: Oxford University Press, 2000, 240 s. ISBN 0-631-20818-6.

DAVIES, Douglas J. 2002. Death, Ritual and Belief. London, New York: Continuum, 2002. 263 s. ISBN 0-8264-5484-4.

DAVIES, Douglas J. Stručné dějiny smrti. Praha: Volvox Globator, 2007. 188 s. ISBN 978-80-7207-628-4.

42 Je přitom př́značné, že masová spotřeba je v české společnosti značně manipulována (Večerník 2010), a zároveň zde pohřební firmy ze zákona nesmějí (na rozdíl od jiných států) inzerovat svoje služby. 
Olga Nešporová: Obřady loučení se zesnulými: Sekulární, náboženské nebo raději žádné pohřby?

DAVIES, Douglas J.; MATES, Lewis H. Encyclopedia of Cremation. Aldershot: Ashgate, 2005. 488 s. ISBN 0-7546-3773-5.

DOWNEY, William E. Secular Rites. Christian Century, 1998, č. 11, s. 358-359. ISSN 0009-5281.

ELIAS, Norbert. 1998. O osamělosti umírajících v našich dnech. Praha: Nakladatelství Franze Kafky, 1998. 66 s. ISBN 80-85844-39-7.

GENNEP, Arnold van. Přechodové rituály. Systematické studium rituálů. Praha: Lidové noviny, 1997. 201 s. ISBN 80-7106-178-6.

GARCES-FOLEY, Kathleen; HOLCOMB, Justin S. Contemporary American Funerals: Personalizing Tradition. In GARCES-FOLEY, K. (ed.), Death and Religion in a Changing World. Armonk, London: M. E. Sharpe, 2006, s. 207-227. ISBN 0-7656-1221.

GORER, Geoffrey. Death, Grief, and Mourning. Garden City: A Doubleday Anchor Book, 1967. 184 s.

GRIDER, Sylvia. 2006. Spontaneous Shrines and Public Memoralization. In: GARCES-FOLEY, K. (ed.), Death and Religion in a Changing World. Armonk, London: M. E. Sharpe, 2006, s. 246-264. ISBN 0-7656-1221-6.

HAMPLOVÁ, Dana; ŘEHÁKOVÁ, Blanka. Česká religiozita na počátku 3. tisíciletí. Výsledky Mezinárodního programu sociálního výzkumu ISSP 2008 - Náboženství. Praha: Sociologický ústav AV ČR, 2009. 139 s. ISBN 978-80-7330-163-7.

HAŠKOVCOVÁ, Helena. Thanatologie. Nauka o umírání a smrti. Praha: Galén, 2000. 191 s. ISBN 80-7262-034-7.

HEELAS, Paul; WOODHEAD, Linda. The Spiritual Revolution. Why Religion is Giving Way to Spirituality. Malden, Oxford: Blackwell, 2005. 204 s. ISBN 1-4051-1958-6.

HERTZ, Robert. Death and the Right Hand. London: Cohen and West, 1960. $174 \mathrm{~s}$

HERVIEU-LÉGER, Danièle. 2004. Un rituel funéraire de haute modernité. In: LENOIR, F., TONNAC, J.-P. de (eds.). La Mort et l'Immortalité. Encyclopédie des Savoirs et des Croyances. Paris: Bayard, 2004. s. 1608-1624. ISBN 2-227-47134-4.

HOLY, Ladislav; STUCHLIK, Milan. The Structure of Folk Models. London, New York: Academic Press, 1981. $369 \mathrm{~s}$.

HOWARTH, Glennys. Last Rites. The Work of Modern Funeral Director. Amityville, New York: Baywood, 1996. 224 s. ISBN: 0-89503-134-5.

HOWARTH, Glennys. Death and Dying. A Sociological Introduction. Cambridge: Polity, 2007, $301 \mathrm{s.}$ ISBN 0-7456-2533-9.

HUNT, Stephen. Religion and Everyday Life. London, New York: Routledge, 2005. 200 s. ISBN 0-415-351554-5.

CHLUP, Radek. Struktura a antistruktura. Rituál v pojetí Victora Turnera II. Religio. Revue pro religionistiku, 2005, č. 2, s.179-197. ISSN 1210-3640.

JUPP, Peter C. From Dust to Ashes. Cremation and the British Way of Death. Basingstoke - New York: Palgrave Macmillan, 2006, 232 s. ISSN 978-0-333-69298-1.

KORDULE, Stanislav. Kremace se stanoviska církve ČSL. Žeh, 1937, roč. 28, s. 86-87.

KUNSTOVNÝ, Otakar. Narození, sňatek a pohřeb volného myslitele. Praha: Volná myšlenka, nedatováno.

LENDEROVÁ, Milena. S pietou popel shrnouce... aneb kremace v Čechách. Déjiny a současnost, 2001, č. 1, s. 23-27. ISSN 0418-5129.

LOUKOTKA, Jiř́i. Védecký ateismus a světonázorová výchova. Praha: Horizont, 1979, 342 s.

MAIELLO, Giuseppe. Současné pohřební rituály v českých zemích na př́íkladu krematorií v Praze-Strašnicích, Zlíně a Plzni. Český lid, 2005, č. 1, s. 35-47. ISSN 0009-0794.

MALINOWSKI, Bronislaw. Magic, Science and Religion, and Other Essays. Garden City: Doubleday, 1954, $274 \mathrm{~s}$.

MENCL, F[rantišek] X. Pohřeb ohněm. Několik kapitol o zpopelňováni mrtvých. Praha: Krematorium, 1922. $32 \mathrm{~s}$. 
MERRIDALE, Catherine. Night of Stone. Death and Memory in Russia. London: Granta Books, 2000, $506 \mathrm{~s}$. ISBN 1-86207-452-6.

NAVRÁTILOVÁ, Alexandra. 1989. „K analýze tendencí vývoje rodinných obřadů na současné vesnici. Obřady spojené s úmrtím a pohřbem.“ Český lid, 1989, roč. 76, s. 149-155. ISSN 0009-0794.

NEŠPOR, Zdeněk R. Religious Processes in Contemporary Czech Society. Sociologický časopis/Czech Sociological Review, 2004, č. 3, s. 277-295. ISSN 0038-0288.

NEŠPOR, Zdeněk R.; NEŠPOROVÁ, Olga. V žáru lásky se život započal - v žáru ohně se končí. Sociologický časopis/Czech Sociological Review, 2011, v recenzním řízení. ISSN 0038-0288.

NEŠPOROVÁ, Olga. Smrt, umírání a pohřební rituály v české společnosti ve 20. století. Soudobé dějiny, 2007, č. 2-3, s. 354-378. ISSN 1210-7050.

NEŠPOROVÁ, Olga. Reflexe smrti a pohřebni obřady v současné české společnosti. Praha: UK FHS, doktorská práce, 2008. $236 \mathrm{~s}$.

NEŠPOROVÁ, Olga; NEŠPOR, Zdeněk R. Religion: An Unsolved Problem for the Modern Czech Nation. Sociologický časopis/Czech Sociological Review, 2009, č. 6. s. 1215-1237. ISSN 0038-0288.

NOZAR, Karel. Pohřby do zemé a kremace. Praha: Krematorium, 1931. 15 s.

Občanské obřady. Občanské obřady. Brno: Okresní kulturní středisko, 1978.

O'DEA, Thomas F.; O'DEA AVIAD, Janet. The Sociology of Religion. 2. vyd. Englewood Cliffs: Prentice-Hall, 1983. 135 s. ISBN 0-13-821058-6.

Pohřební proslovy. Pohřební proslovy. Praha: Volná myšlenka, 1930. 57 s.

QUARTIER, Thomas. Personal Symbols in Roman Catholic Funerals in the Netherlands. Mortality, 2009, č. 2, s. 133-146. ISSN 1357-6275.

SCHÄFER, Cyril Timo. Post-mortem Personalization: An Ethnographic Study of Funeral Directors in New Zealand. Otago: Unpublished doctoral dissertation at University of Otago, 2005. s. 279.

SCHULZ, Felix Robin. 2005. Death in East Germany, 1945-1990. York: Unpublished doctoral dissertation at University of York, 2005, 346 s.

SINGLY, François de. 1999. Sociologie současné rodiny. Praha: Portál, 1999, 127 s. ISBN 80-7178-249-1.

SOŠKOVÁ, Jana. Jednota světonázorového obsahu a estetickej formy občianskej obradnosti. Ateizmus, 1984 , č. 5, s. 435-445.

Společnost přátel žehu. Společnost přátel žehu 1909-2009. Praha: Společnost přátel žehu, 2009. 61 s.

SUDNOW, David. Passing on. The Social Organization of Dying. New Persey: Prentice-Hall, 1967, 176 s.

ŠKVARKA, J. Niektoré aspekty organizovania občianskych obradov. Ateizmus, 1975. č. 3, s. 356-359.

TURNER, Victor. Prüběh rituálu. Brno: Computer Press, 2004, 194 s. ISBN 80-7226-900-3.

VANDENDORPE, Florence. Funerals in Belgium: The Hidden Complexity of Contemporary Practices. Mortality, 2000, č. 1, s. 18-33. ISSN 1357-6275.

VEČERNÍK, Jiří. Konzumní společnost - vstup do ráje hojnosti a manipulace. In: MAŘíKOVÁ, H., KOSTELECKÝ, T., LEBEDA, T., ŠKODOVÁ, M. (eds.) Jaká je naše společnost? Praha: Sociologické nakladatelství, 2010, s. 100-113. ISBN 978-80-7419-025-4.

VENBRUX, Eric; PEELEN, Janneke; ALTENA, Marga. 2009. Going Dutch: Individualization, Secularisation and Changes in Death Rites. Mortality, 2009, č. 2, s. 97-101. ISSN 1357-6275.

WALTER, Tony. Funerals and How to Improve Them. London: Hodder \& Stoughton, 1990, 306 s. ISBN 0-340-53125-8.

WALTER, Tony. The Revival of Death. London; New York: Routledge, 1994, 228 s. ISBN 0-415-11854-9.

WALTER, Tony. On Bereavement: The Culture of Grief. Buckingham, Philadelphia: Open University Press, 1999, 232 s. ISBN 0-335-20081-8.

WIENRICH, Stephanie; SPEYER, Josefine (eds.). The Natural Death Handbook. London: Rider, 2003, 382 s. ISBN 1-8441-3226-9.

WILLSON, Jane Wynne. Funerals Without God. A Practical Guide to Non-Religious Funerals. Amherst: Promethus Books, 1990, 64 s. ISBN 978-0-87975-641. 
Olga Nešporová: Obřady loučení se zesnulými: Sekulární, náboženské nebo raději žádné pohřby?

\section{Autorka}

Olga Nešporová vystudovala antropologii na Fakultě humanitních studií Univerzity Karlovy v Praze, doktorát ze sociální antropologie získala tamtéž. Od roku 2004 působí ve Výzkumném ústavu práce a sociálních věcí. Hlavními oblastmi jejího odborného zájmu jsou smrt a pohřební obřady, a dále sociologie rodiny, kde se zaměřuje především na rodičovství, slad'ování pracovního a rodinného života a mezigenerační solidaritu.

Kontakt: olga.nesporova@vupsv.cz 